\title{
Facile Multicomponent Polymerizations toward Multifunctional Heterochain Polymers with $\boldsymbol{\alpha}, \boldsymbol{\beta}$-Unsaturated Amidines
}

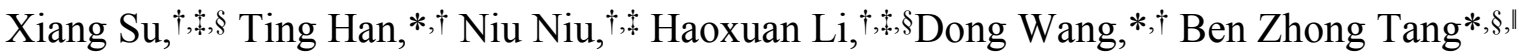

†Center for AIE Research, Shenzhen Key Laboratory of Polymer Science and Technology, Guangdong Research Center for Interfacial Engineering of Functional Materials, College of Materials Science and Engineering, Shenzhen University, Shenzhen 518060, China

College of Physics and Optoelectronic Engineering, Shenzhen University, Shenzhen 518060, China $\S$ Department of Chemistry, Hong Kong Branch of Chinese National Engineering Research Center for Tissue Restoration and Reconstruction, The Hong Kong University of Science and Technology, Clear Water Bay, Kowloon, Hong Kong, China

"Shenzhen Institute of Aggregate Science and Technology, School of Science and Engineering, The Chinese University of Hong Kong, Shenzhen, Guangdong 518172, China 


\section{Table of Contents}

Experimental procedures

Scheme S1. Proposed mechanism of a $\mathrm{Cu}(\mathrm{I})$-catalyzed three-component reaction of alkyne, sulfonyl azide, and $N, N$-dimethylformamide dimethyl acetal.

Table S1. Effect of solvent on the polymerization of 1a, $\mathbf{2 a}$ and $\mathbf{3}$.

Figure S1. (A) Normalized GPC curves of the polymers obtained at different reaction time. (B) Change in the $M_{\mathrm{w}}$ of the polymers obtained at different polymerization time.

Scheme S2. Synthetic routes to monomer 1e.

Scheme S3. Synthetic route to model compound 5

$\mathrm{S} 10$

Figure S2. ${ }^{1} \mathrm{H}$ NMR spectrum of model compound 5 in $\mathrm{CDCl}_{3}$.

$\mathrm{S} 10$

Figure S3. ${ }^{13} \mathrm{C}$ NMR spectrum of model compound 5 in $\mathrm{CDCl}_{3}$.

S11

Figure S4. X-ray crystal structure of model compound 5 (CCDC number: 986538).

S1 1

Figure S5. ${ }^{1} \mathrm{H}$ NMR spectra of (A) crude reaction mixture of the model reaction of phenylacetylene, tosyl azide and 3 and (B) the pure reaction product (compound 5) in $\mathrm{CDCl}_{3}$.

Figure S6. ${ }^{1} \mathrm{H}$ NMR spectra of (A) crude reaction mixture of the polymerization of 1a, $\mathbf{2 a}$ and $\mathbf{3}$ and (B) the pure polymeric product $(\mathrm{P} \mathbf{1} \mathbf{a} / \mathbf{2} \mathbf{a} / \mathbf{3})$ in $\mathrm{DMSO}-d_{6}$.

Figure S7. IR spectra of (A) 1b, (B) 2a, (C) 3, (D) model compound 4, and (E) P1b/2a/3. S13

Figure S8. IR spectra of (A) P1a/2a/3, (B) P1b/2a/3, (C) P1c/2a/3, (D) P1d/2a/3, (E) P1e/2a/3, and (F) $\mathrm{P} \mathbf{1 b} / \mathbf{2 b} / \mathbf{3}$.

Figure S9. ${ }^{1} \mathrm{H}$ NMR spectra of (A) 1a, (B) 2a, (C) 3, and (D) model compound 4 in $\mathrm{CDCl}_{3}$ and (E) $\mathrm{P} \mathbf{1} / \mathbf{2} \mathbf{2} / \mathbf{3}$ in DMSO- $d_{6}$.

Figure S10. ${ }^{13} \mathrm{C}$ NMR spectra of (A) 1a, (B) 2a, (C) 3, and (D) model compound $\mathbf{4}$ in $\mathrm{CDCl}_{3}$ and (E) $\mathrm{P} \mathbf{1 a} / \mathbf{2 a} / \mathbf{3}$ in DMSO- $d_{6}$.

Figure S11. ${ }^{1} \mathrm{H}$ NMR spectra of (A) 1c, (B) 2a, (C) 3, and (D) model compound 4 in $\mathrm{CDCl}_{3}$ and (E) $\mathrm{P} \mathbf{1} / \mathbf{2 a} / \mathbf{3}$ in DMSO- $d_{6}$.

Figure S12. ${ }^{13} \mathrm{C}$ NMR spectra of (A) 1c, (B) 2a, (C) 3, and (D) model compound 4 in $\mathrm{CDCl}_{3}$ and (E) $\mathrm{P} \mathbf{1} / \mathbf{2 a} / \mathbf{3}$ in DMSO- $d_{6}$.

Figure S13. ${ }^{1} \mathrm{H}$ NMR spectra of (A) 1d, (B) 2a, (C) 3, and (D) model compound 4 in $\mathrm{CDCl}_{3}$ and (E) $\mathrm{P} \mathbf{1 d} / \mathbf{2 a} / \mathbf{3}$ in DMSO- $d_{6}$.

Figure S14. ${ }^{13} \mathrm{C}$ NMR spectra of (A) 1d, (B) 2a, (C) 3, and (D) model compound 4 in $\mathrm{CDCl}_{3}$ and (E) $\mathrm{P} \mathbf{1 d} / \mathbf{2} \mathbf{a} / \mathbf{3}$ in DMSO- $d_{6}$.

Figure S15. ${ }^{1} \mathrm{H}$ NMR spectra of (A) 1e, (B) 2a, (C) 3, and (D) model compound 4 in $\mathrm{CDCl}_{3}$ and (E) $\mathrm{P} \mathbf{1} / \mathbf{2} \mathbf{a} / \mathbf{3}$ in DMSO- $d_{6}$.

Figure S16. ${ }^{13} \mathrm{C}$ NMR spectra of (A) 1e, (B) 2a, (C) 3, and (D) model compound 4 in $\mathrm{CDCl}_{3}$ and (E) $\mathrm{P} \mathbf{1 e} / \mathbf{2} \mathbf{a} / \mathbf{3}$ in DMSO- $d_{6}$.

Figure S17. ${ }^{1} \mathrm{H}$ NMR spectra of (A) 1b, (B) 2b, (C) 3, and (D) model compound 4 in $\mathrm{CDCl}_{3}$ and (E) $\mathrm{P} \mathbf{1 b} / \mathbf{2} \mathbf{b} / \mathbf{3}$ in DMSO$-d_{6}$.

Figure S18. ${ }^{13} \mathrm{C}$ NMR spectra of (A) $\mathbf{1 b},(\mathrm{B}) \mathbf{2 b},(\mathrm{C}) \mathbf{3}$, and (D) model compound $\mathbf{4}$ in $\mathrm{CDCl}_{3}$ and (E) $\mathrm{P} \mathbf{1 b} / \mathbf{2} \mathbf{b} / \mathbf{3}$ in DMSO- $d_{6}$.

Figure S19. (A) TGA thermograms of P1a-e/2a-b/3 recorded under nitrogen at a heating rate of 10 ${ }^{\circ} \mathrm{C} / \mathrm{min}$. (B) DSC thermograms of $\mathrm{P} \mathbf{1} \mathbf{a}-\mathbf{e} / \mathbf{2} \mathbf{a}-\mathbf{b} / \mathbf{3}$ recorded under nitrogen during the second heating cycle at a heating rate of $10 \quad 10 \quad{ }^{\circ} \mathrm{C} / \mathrm{min}$. S25

Figure S20. UV spectra and the maximum absorption wavelength of P1a-e/2a-b/3 and $\mathbf{4}$ in DMF solutions. Solution concentration: $10 \mu \mathrm{M}$.

Figure S21. PL spectra model compound 4 in DMF/water mixtures with different water fractions $\left(f_{\mathrm{w}}\right)$. 
Solution concentration: $10 \mu \mathrm{M}$. Excitation wavelength $=325 \mathrm{~nm}$.

Figure S22. Emission spectra of P1e/2a/3 in (A) DMF and (B) $90 \%$ water $+10 \%$ DMF with the addition of different volume of $\mathrm{HCl}$ aqueous solution $(1.0 \mathrm{M})$. Polymer concentration: $10 \mu \mathrm{M}$. Excitation wavelength $=365 \mathrm{~nm}$.

Figure S23. Emission spectra of P1b/2a/3 in (A) DMF and (B) $90 \%$ water $+10 \%$ DMF with the addition of different volume of $\mathrm{HCl}$ aqueous solution $(1.0 \mathrm{M})$. Polymer concentration: $10 \mu \mathrm{M}$. Excitation wavelength $=340 \mathrm{~nm}$.

S26

Figure S24. Fluorescence detection of $\mathrm{Ru}^{3+}$ using P1b/2a/3. (A) Emission spectra of P1b/2a/3 $(10 \mu \mathrm{M})$ in $\mathrm{DMF} /$ water mixtures with a water fraction of $90 \%$ containing different metal cations $(100 \mu \mathrm{M})$. Excitation wavelength $=365 \mathrm{~nm}$. (B) Relative intensity $\left(I_{0} / I\right)$ of $\mathbf{P} \mathbf{1 b} / \mathbf{2 a} / \mathbf{3}$ in DMF/water mixtures with a water fraction of $90 \%$ containing different metal ions. $I_{0}=$ fluorescence intensity in the absence of metal cations. Inset: fluorescence photographs of $\mathrm{P} \mathbf{1 b} / \mathbf{2 a} / \mathbf{3}$ in DMF/water mixtures with a water fraction of $90 \%$ containing different metal ions. The photos were taken under $365 \mathrm{~nm}$ UV irradiation.

Figure S25. Emission spectra of $\mathrm{P} \mathbf{1 e} / \mathbf{2 a} / \mathbf{3}(10 \mu \mathrm{M})$ in DMF/water mixtures with $90 \%$ aqueous buffer solution $(\mathrm{pH}=1)$ containing different metal cations $(10 \mu \mathrm{M})$. Excitation wavelength $=365 \mathrm{~nm}$.

Figure S26. The enrichment efficiency of different metal ions using the solid powder of $\mathrm{P} \mathbf{1} / \mathbf{2} \mathbf{2} / \mathbf{3} \cdot\left[\mathrm{M}^{\mathrm{n}+}\right]_{0}$ $=100 \mathrm{mg} / \mathrm{L}, \mathrm{V}_{\mathrm{M}}^{\mathrm{n}+}=2 \mathrm{~mL}, \mathrm{~m}_{\mathrm{P} 1 \mathrm{e} / \mathbf{2} \mathrm{a} / \mathbf{3}}=4 \mathrm{mg}$. Polymer powder and the aqueous solution of metal ions were stirred at room temperature for $1 \mathrm{~h}$ before centrifugation.

S28

Figure S27. (A-C) XPS spectra and (D-F) the associated normalized XPS spectra for (A and D) S 2p, (B and E) O 1 s, and (C and F) N 1s of P1b/2a/3 and P1b/2a/3-Au ${ }^{3+}$.

Figure S28. XPS spectra for (A) S 2p, (B) O 1s, and (C) N 1s of P1e/2a/3 and P1e/2a/3-Au ${ }^{3+}$. $\quad$ S29 Figure S29. (A) Bright-field images, (B) Fluorescence images, and (C) the associated merged images of 4T1 cells stained with $10 \mu \mathrm{M}$ of $\mathrm{P} \mathbf{1 b} / \mathbf{2 a} / \mathbf{3}$. Scale bar $=5 \mu \mathrm{m}$. (D) Bright-field images, (E) Fluorescence images, and $(\mathrm{F})$ the associated merged images of $3 \mathrm{~T} 3$ cells stained with $10 \mu \mathrm{M}$ of $\mathrm{P} \mathbf{1 b} / \mathbf{2 a} / \mathbf{3}$. Scale bar $=$ $10 \mu \mathrm{m}$. Excitation wavelength: $405 \mathrm{~nm}$; emission filter: 450-650 nm.

S29

Reference

S29 


\section{Experimental Procedures}

\section{Materials and Methods}

$\mathrm{N}, \mathrm{N}$-dimethylformamide dimethyl acetal (3), 1,2-bis(diphenylphosphino)ethane (dppe), $\mathrm{PPh}_{3}, \mathrm{CuBr}$, $\mathrm{CuCl}, \mathrm{CuI}$, and $3 \AA$ molecular sieve (MS) powder were purchased from commercial suppliers and used as received without further purification. Solvents such as dichloromethane (DCM), 1,2-dichloroethane (DCE) and tetrahydrofuran (THF) were ultra-dry reagents with molecular sieves and were purchased from J\&K Scientific. Toluene was freshly distilled over sodium to remove $\mathrm{H}_{2} \mathrm{O}$ before use. Diynes 1a-d, disulfonyl azide 2a-b, (2-(4-ethynylphenyl)ethene-1,1,2-triyl)tribenzene, and $p$-toluenesulfonyl azide were prepared according to the previously reported procedures ${ }^{[1]}$ Buffer solutions with $\mathrm{pH}$ ranging from 1.1 to 7.1 were prepared by adding different amount of $1 \mathrm{M} \mathrm{HCl}$ to $\mathrm{PBS}(\mathrm{pH}=7.2-7.4)$. The standard solutions $\left(\left[\mathrm{M}^{\mathrm{n}+}\right]=1000 \mathrm{mg} / \mathrm{L}\right)$ of gold, copper, cobalt, nickel, cadmium, manganese, palladium and ruthenium and the standard solutions $\left(\left[\mathrm{M}^{\mathrm{n}+}\right]=10000 \mathrm{mg} / \mathrm{L}\right)$ of calcium, magnesium and sodium were purchased from Meryer.

${ }^{1} \mathrm{H}$ and ${ }^{13} \mathrm{C}$ NMR spectra were estimated on a Bruker AVANCE III 600 or $500 \mathrm{MHz} \mathrm{NMR}$ spectrometer. Chemical shifts were calibrated using $\mathrm{CDCl}_{3}\left({ }^{1} \mathrm{H}\right.$ NMR: $\delta 7.26 \mathrm{ppm} ;{ }^{13} \mathrm{C}$ NMR: $\delta 77.16$ ppm) or DMSO- $d_{6}\left({ }^{1} \mathrm{H}\right.$ NMR: $\delta 2.50 \mathrm{ppm} ;{ }^{13} \mathrm{C}$ NMR: $\left.\delta 39.52 \mathrm{ppm}\right)$ as internal reference. FT-IR spectra were determined on a Nicolet 6700 FTIR spectrophotometer ( $\mathrm{KBr}$ disk). Weight-average molecular weights $\left(M_{\mathrm{w}}\right)$, number-average molecular weights $\left(M_{\mathrm{n}}\right)$ and polydispersity indices (PDI, $\left.M_{\mathrm{w}} / M_{\mathrm{n}}\right)$ of the obtained polymers were estimated by Waters 1525 gel permeation chromatography system using RI detector and calibrated using a set of monodispersed polystyrene standards. DMF/LiBr solution ( $0.05 \mathrm{M}$ $\mathrm{LiBr}$ ) was used as eluent at a flow rate of $1 \mathrm{~mL} / \mathrm{min}$. Thermogravimetric analysis (TGA) and differential scanning calorimetry (DSC) measurement was carried out on a TA TGA 55 and a TA DSC Q200, respectively, under nitrogen at a heating rate of $10{ }^{\circ} \mathrm{C} / \mathrm{min}$. UV-vis spectra and PL spectra were measured on a Shimadzu UV-2450 UV/Vis spectrophotometer and a Edinburgh FS5 Fluorescence Spectrometer, respectively. XPS measurements were performed by Thermo Scientific K-Alpha ${ }^{+}$. The concentrations of metal ions were measured with inductively coupled plasma-optical emission spectroscopy (ICP-OES) by ICAP 7000 SERIES.

\section{Synthesis and Characterization}

Synthesis of monomer 1e: The synthetic routes of 1e were provided in Scheme S2 and the detailed experimental procedures were given as below.

(i) Synthesis of compound 2: To a sealed tube was charged with the mixture of compound $\mathbf{1}$ (2 mmol, 768 $\mathrm{mg}$ ) (prepared according to the previously reported procedure $\left.{ }^{[2]}\right), \mathrm{Pd}\left(\mathrm{PPh}_{3}\right)_{2} \mathrm{Cl}_{2}(2 \mathrm{~mol} \%, 28 \mathrm{mg}), \mathrm{CuI}(2$ mol\%, $8 \mathrm{mg})$ and $\mathrm{PPh}_{3}(1 \mathrm{~mol} \%, 5.3 \mathrm{mg})$. The tube was evacuated and recharged with $\mathrm{N}_{2}$ for 3 times. Then ethynyltrimethylsilane $(2.6 \mathrm{mmol}, 370 \mu \mathrm{L})$, THF $(2 \mathrm{mmol}, 1.02 \mathrm{~g})$ and $\mathrm{Et}_{3} \mathrm{~N}(2 \mathrm{~mL})$ were added and the mixture was stirred at $70{ }^{\circ} \mathrm{C}$ for $16 \mathrm{~h}$. Afterward, the reaction mixture was stopped and cooled to room temperature. After being extracted with DCM $(10 \mathrm{~mL} \times 3)$, the organic layer was dried over anhydrous $\mathrm{MgSO}_{4}$. Evaporation of the solvent followed by purification on a silica gel column (eluent: hexane/EtOAc $=15 / 1, \mathrm{v} / \mathrm{v}$ ) provided the compound 2 as a light yellow thick liquid (593 mg, 85\% yield). ${ }^{1} \mathrm{H}$ NMR (600 
$\left.\mathrm{MHz}, \mathrm{CDCl}_{3}\right), \delta(\mathrm{ppm}): 7.73(\mathrm{dd}, J=4.8,4.2 \mathrm{~Hz}, 2 \mathrm{H}), 7.67-7.64(\mathrm{~m}, 2 \mathrm{H}), 7.55-7.51(\mathrm{~m}, 2 \mathrm{H}), 6.62(\mathrm{dd}, J$ $=9.2,2.5 \mathrm{~Hz}, 2 \mathrm{H}), 3.39$ (q, $J=7.3 \mathrm{~Hz}, 4 \mathrm{H}), 1.17(\mathrm{t}, J=7.2 \mathrm{~Hz}, 6 \mathrm{H}), 0.28(\mathrm{~s}, 9 \mathrm{H}) .{ }^{13} \mathrm{C} \mathrm{NMR}(100 \mathrm{MHz}$, $\left.\mathrm{CDCl}_{3}\right), \delta(\mathrm{ppm}): 193.66(\mathrm{C}=\mathrm{O}), 151.08,139.02,132.90,131.45,129.19,125.70,123.59,110.04,104.46$, 96.50, $44.46\left(\mathrm{CH}_{2}\right), 12.45\left(\mathrm{CH}_{3}\right),-0.14\left(\mathrm{CH}_{3}\right)$.

(ii) Synthesis of compound 3: Compound 2 (428 mg, $1.22 \mathrm{mmol})$ and zinc powder (160 mg, $2.5 \mathrm{mmol})$ were placed in a degassed flask. Then $20 \mathrm{~mL}$ of dry THF was added and the mixture was cooled to -78 ${ }^{\circ} \mathrm{C}$. Subsequently, $\mathrm{TiCl}_{4}(143 \mu \mathrm{L}, 1.3 \mathrm{mmol})$ was added dropwise to the suspension. Then the temperature was slowly increased to room temperature. After reacting at room temperature for $0.5 \mathrm{~h}$, the mixture was heated to reflux and stirred overnight. Then the reaction mixture was quenched with $10 \%$ aqueous solution of $\mathrm{K}_{2} \mathrm{CO}_{3}$ and extracted with DCM $(10 \mathrm{~mL} \times 3)$. The organic layer was dried over anhydrous $\mathrm{MgSO}_{4}$. Then the solvent was evaporated and the crude reaction mixture was purified by silica gel chromatography using hexane/EtOAc/DCM (20/1/1, v/v) as eluent. Finally, compound 3 was obtained as an orange-red solid (305 mg, 75\% yield). ${ }^{1} \mathrm{H}$ NMR (600 MHz, $\left.\mathrm{CDCl}_{3}\right), \delta(\mathrm{ppm}):$ 7.27-7.24 (m, 2H), 7.20 (dd, $J=8.2$, $1.4 \mathrm{~Hz}, 1 \mathrm{H}), 7.08(\mathrm{dd}, J=8.2,1.5 \mathrm{~Hz}, 2 \mathrm{H}), 7.00(\mathrm{dd}, J=8.2,1.5 \mathrm{~Hz}, 1 \mathrm{H}), 6.86(\mathrm{dd}, J=8.7,1.6 \mathrm{~Hz}, 1 \mathrm{H})$, $6.77(\mathrm{dd}, J=8.7,1.6 \mathrm{~Hz}, 2 \mathrm{H}), 6.46-6.44(\mathrm{~m}, 1 \mathrm{H}), 6.41-6.36(\mathrm{~m}, 2 \mathrm{H}), 3.32(\mathrm{q}, J=6.9 \mathrm{~Hz}, 8 \mathrm{H}), 1.15(\mathrm{t}, J$ $=7.0 \mathrm{~Hz}, 12 \mathrm{H}), 0.27(\mathrm{~d}, J=1.7 \mathrm{~Hz}, 18 \mathrm{H}) \cdot{ }^{13} \mathrm{C} \mathrm{NMR}\left(100 \mathrm{MHz}, \mathrm{CDCl}_{3}\right), \delta(\mathrm{ppm}): 146.41,146.35,146.10$, $145.77,138.83,138.79,132.80,132.62,131.80,131.70,131.37,131.31,130.86,130.56,120.28,120.05$, $110.95,110.83,105.96,93.79,44.33\left(\mathrm{CH}_{2}\right), 44.24\left(\mathrm{CH}_{2}\right), 12.79\left(\mathrm{CH}_{3}\right), 12.76\left(\mathrm{CH}_{3}\right), 0.16\left(\mathrm{CH}_{3}\right), 0.15$ $\left(\mathrm{CH}_{3}\right)$.

(iii) Synthesis of compound 1e: To a screw-capped tube was added compound 3 (0.3 mmol, $205 \mathrm{mg})$, $\mathrm{K}_{2} \mathrm{CO}_{3}(0.6 \mathrm{mmol}, 82.8 \mathrm{mg})$, THF $(2 \mathrm{~mL})$, and $\mathrm{MeOH}(2 \mathrm{~mL})$ sequentially. The tube was allowed to stir at room temperature for $12 \mathrm{~h}$. After the reaction was completed, the mixture was extracted with DCM (5 $\mathrm{mL} \times 3$ ). The organic layer was dried over anhydrous $\mathrm{MgSO}_{4}$. Then the solvent was evaporated and the crude reaction mixture was purified by silica gel chromatography using hexane/EtOAc/DCM (20/1/1, $\mathrm{v} / \mathrm{v})$ as eluent. Monomer 1e was obtained as an orange-red solid (141 mg, 90\% yield). ${ }^{1} \mathrm{H}$ NMR (600 $\left.\mathrm{MHz}, \mathrm{CDCl}_{3}\right), \delta(\mathrm{ppm}): 7.29-7.21(\mathrm{~m}, 4 \mathrm{H}), 7.12-7.00(\mathrm{~m}, 4 \mathrm{H}), 6.89$ - $6.76(\mathrm{~m}, 4 \mathrm{H}), 6.48-6.37(\mathrm{~m}, 4 \mathrm{H})$, 3.36-3.27 (m, 8H), 3.07-3.02 (m, 2H), 1.18-1.10 (m, 12H). $\left.{ }^{13} \mathrm{C} \mathrm{NMR} \mathrm{(100} \mathrm{MHz,} \mathrm{CDCl}_{3}\right), \delta(\mathrm{ppm}): 146.46$, $146.40,146.28,146.01,138.87,138.81,132.78,132.60,131.85,131.74,131.51,131.48,130.80,130.47$, $119.32,119.12,110.99,110.91,84.43,84.22,77.06,76.87,44.33\left(\mathrm{CH}_{2}\right), 44.27\left(\mathrm{CH}_{2}\right), 12.76\left(\mathrm{CH}_{3}\right)$.

Model reaction: The synthetic procedures of model compound 4 were provided as follows. To an ovendried 4-mL vial or a screw-capped tube was sequentially added (2-(4-ethynylphenyl)ethene-1,1,2triyl)tribenzene ( $85.4 \mathrm{mg}, 0.24 \mathrm{mmol}), p$-toluenesulfonyl azide ( $47.3 \mathrm{mg}, 0.24 \mathrm{mmol}), \mathrm{CuBr}(2.9 \mathrm{mg}, 0.02$ $\mathrm{mmol})$, dppe ( $8 \mathrm{mg}, 0.02 \mathrm{mmol}), 3 \AA \mathrm{MS}$ powder $(40 \mathrm{mg})$, DCM (2 mL), and $N, N$-dimethylformamide dimethyl acetal $(27 \mu \mathrm{L}, 0.2 \mathrm{mmol})$ under $\mathrm{N}_{2}$ atmosphere in oven-dried glassware. The reaction mixture was stirred at room temperature for $12 \mathrm{~h}$. After solvent removal, the residue was purified by silica gel flash column chromatography (eluent: hexane/EtOAc $=2 / 1, \mathrm{v} / \mathrm{v}$ ) to give the desired product 4 as a white solid in a yield of $81 \%$. IR (neat), $v\left(\mathrm{~cm}^{-1}\right)$ : 3024, 2927, 2850, 1639, 1539, 1257, 1088. ${ }^{1} \mathrm{H}$ NMR $(500$ $\left.\mathrm{MHz}, \mathrm{CDCl}_{3}\right), \delta(\mathrm{ppm}): 7.71(\mathrm{~d}, J=8.2 \mathrm{~Hz}, 2 \mathrm{H}), 7.15-6.97(\mathrm{~m}, 20 \mathrm{H}), 6.88(\mathrm{~d}, J=8.5 \mathrm{~Hz}, 2 \mathrm{H}), 6.56(\mathrm{~s}$, $1 \mathrm{H}), 3.81(\mathrm{~s}, 3 \mathrm{H}), 3.07(\mathrm{~s}, 3 \mathrm{H}), 2.70(\mathrm{~s}, 3 \mathrm{H}), 2.33(\mathrm{~s}, 3 \mathrm{H}) .{ }^{13} \mathrm{C} \mathrm{NMR}\left(100 \mathrm{MHz}, \mathrm{CDCl}_{3}\right), \delta(\mathrm{ppm}): 165.80$, $152.21,143.95,143.74,143.51,142.15,141.56,141.51,141.10,140.88,131.51,131.47,131.45,131.33$, $131.31,128.93,127.76,127.64,126.95,126.90,126.59,126.57,126.47,110.69,61.84,39.42,38.61$, 21.53. Model compound 5 was synthesized according to reported procedures. ${ }^{[3]}$ 
Polymer synthesis: The synthetic procedure to P1a/2a/3 (Table 1, entry 15) was given below as an example. To an oven-dried 4-mL vial or a screw-capped tube were sequentially added diyne 1a $(0.1$ mmol), disulfonyl azide ( $0.1 \mathrm{mmol}), \mathrm{CuBr}(2.9 \mathrm{mg}, 0.02 \mathrm{mmol})$, dppe $(8 \mathrm{mg}, 0.02 \mathrm{mmol}), 3 \AA \mathrm{MS}$ powder (40 mg), DCM ( $1 \mathrm{~mL}$ ), and $N, N$-dimethylformamide dimethyl acetal (32 $\mu \mathrm{L}, 0.24 \mathrm{mmol})$ under $\mathrm{N}_{2}$ atmosphere. The reaction mixture was stirred at room temperature for $1 \mathrm{~h}$. Upon completion, the resulting solution was diluted with $3 \mathrm{~mL}$ of DCM and then added dropwise into $150 \mathrm{~mL} \mathrm{Et}_{2} \mathrm{O}$ through a neutral $\mathrm{Al}_{2} \mathrm{O}_{3}$-filled dropper to remove the catalyst and molecular sieve residue. The precipitate was finally collected after filtration, being washed with $\mathrm{Et}_{2} \mathrm{O}$, and dried under vacuum at $50{ }^{\circ} \mathrm{C}$ to a constant weight. The structural characterization results were summarized as follows.

Characterization Data for P1a/2a/3: light yellowish-brown powder. 91\% yield, $M_{\mathrm{n}}: 25300 ; M_{\mathrm{w}}: 45400$; $M_{\mathrm{w}} / M_{\mathrm{n}}: 1.8$ (GPC, polystyrene calibration). IR (neat), $v\left(\mathrm{~cm}^{-1}\right): 2927,2854,1639,1539,1485,1238,1141$, 1087. ${ }^{1} \mathrm{H}$ NMR (500 MHz, DMSO- $\left.d_{6}\right), \delta(\mathrm{ppm}): 7.70,7.65,7.63,7.52,7.50,7.27,7.17,6.87,6.48(\mathrm{CH})$, $3.79\left(\mathrm{CH}_{3}\right), 3.07\left(\mathrm{CH}_{3}\right), 2.75\left(\mathrm{CH}_{3}\right), 1.79,0.95,0.64 .{ }^{13} \mathrm{C}$ NMR (100 MHz, DMSO- $\left.d_{6}\right), \delta(\mathrm{ppm}): 164.98$ $(\mathrm{C}=\mathrm{N}), 157.65,150.14,139.67,131.85,128.68,118.19,110.04,61.59\left(\mathrm{CH}_{3}\right), 54.12,37.87\left(\mathrm{CH}_{3}\right), 30.78$, 28.89, 23.29, 21.76, 13.70 .

Characterization Data for P1b/2a/3: light yellowish-brown powder. 89\% yield, $M_{\mathrm{n}}: 18300 ; M_{\mathrm{w}}: 28200$; $M_{\mathrm{w}} / M_{\mathrm{n}}: 1.6$ (GPC, polystyrene calibration). IR (neat), $v\left(\mathrm{~cm}^{-1}\right): 3054,2935,2846,1639,1539,1485,1242$, 1142, 1088. ${ }^{1} \mathrm{H}$ NMR (500 MHz, DMSO- $\left.d_{6}\right), \delta$ (ppm): 7.69, 7.67, 7.62, 7.49, 7.06, 6.99, 6.94, 6.81, 6.42 $(\mathrm{CH}), 3.71\left(\mathrm{CH}_{3}\right), 2.98\left(\mathrm{CH}_{3}\right), 2.69\left(\mathrm{CH}_{3}\right) .{ }^{13} \mathrm{C} \mathrm{NMR}\left(100 \mathrm{MHz}, \mathrm{DMSO}-d_{6}\right), \delta(\mathrm{ppm}): 164.69(\mathrm{C}=\mathrm{N})$, $157.79,151.72$, 142.98, 141.15, 140.32, 139.67, 131.47, 131.27, 130.71, 130.52, 129.15, 128.72, 127.76, $126.35,118.37,109.34,61.58\left(\mathrm{CH}_{3}\right), 37.90\left(\mathrm{CH}_{3}\right)$.

Characterization Data for P1c/2a/3: light yellowish-brown powder. 91\% yield, $M_{\mathrm{n}}: 29400 ; M_{\mathrm{w}}: 74500$; $M_{\mathrm{w}} / M_{\mathrm{n}}: 2.5$ (GPC, polystyrene calibration). IR (neat), $v\left(\mathrm{~cm}^{-1}\right): 3058,2939,1639,1546,1481,1265,1138$, 1088. ${ }^{1} \mathrm{H}$ NMR (500 MHz, DMSO- $\left.d_{6}\right), \delta$ (ppm): 7.67, 7.65, 7.63, 7.62, 7.50, 7.40, 7.39, 6.94, 6.92, 6.56 $(\mathrm{CH}), 3.82\left(\mathrm{CH}_{3}\right), 3.12\left(\mathrm{CH}_{3}\right), 2.85\left(\mathrm{CH}_{3}\right) .{ }^{13} \mathrm{C}$ NMR $\left(100 \mathrm{MHz}, \mathrm{DMSO}-d_{6}\right), \delta(\mathrm{ppm}): 194.18(\mathrm{C}=\mathrm{O})$, $164.15(\mathrm{C}=\mathrm{N}), 157.78,153.38,139.34,137.16,134.37,133.25,131.48,129.63,129.16,128.84,127.61$, 126.61, 118.69, 118.34, 108.38, $62.08\left(\mathrm{CH}_{3}\right), 37.93\left(\mathrm{CH}_{3}\right)$.

Characterization Data for P1d/2a/3: light yellowish-brown powder. $78 \%$ yield, $M_{\mathrm{n}}: 11000 ; M_{\mathrm{w}}: 18800$; $M_{\mathrm{w}} / M_{\mathrm{n}}: 1.7$ (GPC, polystyrene calibration). IR (neat), $v\left(\mathrm{~cm}^{-1}\right): 3031,2935,2846,1635,1543,1485,1242$, 1138, 1084. ${ }^{1} \mathrm{H}$ NMR $\left(600 \mathrm{MHz}, \mathrm{DMSO}-d_{6}\right), \delta(\mathrm{ppm}): 7.69,7.65,7.64,7.56,7.55,7.53,7.34,6.93,6.89$, $6.43(\mathrm{CH}), 3.79\left(\mathrm{CH}_{3}\right), 3.11\left(\mathrm{CH}_{3}\right), 2.84\left(\mathrm{CH}_{3}\right) .{ }^{13} \mathrm{C}$ NMR (100 MHz, DMSO- $\left.d_{6}\right), \delta(\mathrm{ppm}): 164.08(\mathrm{C}=\mathrm{N})$, $157.14,150.83,138.83,136.55,132.67,131.69,131.51,130.89,128.57,128.14,126.99,126.80,125.91$, 125.66, 125.39, 118.12, 117.72, 108.40, $61.08\left(\mathrm{CH}_{3}\right), 37.29\left(\mathrm{CH}_{3}\right)$.

Characterization Data for P1e/2a/3: yellowish-brown powder. 90\% yield, $M_{\mathrm{n}}$ : 15400; $M_{\mathrm{w}}$ : 24900; $M_{\mathrm{w}} / M_{\mathrm{n}}: 1.6$ (GPC, polystyrene calibration). IR (neat), $v\left(\mathrm{~cm}^{-1}\right): 3031,1639,1605,1543,1516,1485,1400$, 1242, 1142, 1088. ${ }^{1} \mathrm{H}$ NMR (600 MHz, DMSO-d $), \delta(\mathrm{ppm}): 7.71,7.69,7.63,7.51,7.01,6.92,6.89,6.77$, 6.65, 6.43, 6.38, 6.30, $3.71\left(\mathrm{CH}_{3}\right), 3.18(\mathrm{CH} 2), 2.98\left(\mathrm{CH}_{3}\right), 2.67\left(\mathrm{CH}_{3}\right), 0.96\left(\mathrm{CH}_{3}\right) .{ }^{13} \mathrm{C} \mathrm{NMR}(100 \mathrm{MHz}$, DMSO- $\left.d_{6}\right), \delta(\mathrm{ppm}): 164.88(\mathrm{C}=\mathrm{N}), 157.82,145.60,139.73,138.01,132.00,131.47,130.87,130.49$, 129.14, 128.75, 127.58, 126.28, 118.40, 110.33, $61.50\left(\mathrm{CH}_{3}\right), 43.40\left(\mathrm{CH}_{2}\right), 37.97\left(\mathrm{CH}_{3}\right), 12.37\left(\mathrm{CH}_{3}\right)$.

Characterization Data for P1b/2b/3: light yellowish-brown powder. $85 \%$ yield, $M_{\mathrm{n}}: 23400 ; M_{\mathrm{w}}: 63700$; $M_{\mathrm{w}} / M_{\mathrm{n}}: 2.7$ (GPC, polystyrene calibration). IR (neat), $v\left(\mathrm{~cm}^{-1}\right): 3055,2939,1639,1543,1481,1400,1257$, 1145, 1088. ${ }^{1} \mathrm{H}$ NMR (500 MHz, DMSO- $\left.d_{6}\right), \delta(\mathrm{ppm}): 7.74,7.66,7.62,7.47,7.02,6.84,6.78,6.40(\mathrm{CH})$, $3.68\left(\mathrm{CH}_{3}\right), 2.98\left(\mathrm{CH}_{3}\right), 2.68\left(\mathrm{CH}_{3}\right) .{ }^{13} \mathrm{C} \mathrm{NMR}\left(100 \mathrm{MHz}, \mathrm{DMSO}-d_{6}\right), \delta(\mathrm{ppm}): 164.82(\mathrm{C}=\mathrm{N}), 143.73$, $142.79,141.49,141.05,140.31,131.42,130.61,130.41,129.14,127.71,127.04,126.78,126.34,109.36$, $61.54\left(\mathrm{CH}_{3}\right), 37.95\left(\mathrm{CH}_{3}\right)$. 


\section{Cytotoxicity Evaluation}

The cytotoxicity of P1b/2a/3 to different cell lines (normal cells: 3T3, cancer cells: 4T1) was measured by the traditional methylthiazolyldiphenyltetrazolium (MTT) assay according to the manufacturer's method $(n=6)$. For each cell line, the cells were seeded in 96 -well plates at a density of $6 \times 10^{3}$ cells/well. After culture for $24 \mathrm{~h}$, the medium was replaced by fresh medium containing different concentrations of P1b/2a/3. After further incubation for $24 \mathrm{~h}, 10 \mu \mathrm{L}$ solution of MTT $(5 \mathrm{mg} / \mathrm{mL})$ was added into each well and the cells were further incubated at $37^{\circ} \mathrm{C}$ for $3 \mathrm{~h}$. Then the medium was carefully removed and 100 $\mu \mathrm{L}$ DMSO was added to dissolve the purple crystals. The absorption at $570 \mathrm{~nm}$ was measured with a microplate reader (BioTek). Cell viability was calculated according to the following formula:

Cell viability $(\%)=\left(\mathrm{OD}_{\text {sample }}-\mathrm{OD}_{\text {background }}\right) /\left(\mathrm{OD}_{\text {control }}-\mathrm{OD}_{\text {background }}\right) \times 100 \%$

\section{Cell Imaging}

4T1 or 3T3 cells were cultured with RMPI-1640 medium containing $10 \%$ fetal bovine serum and $1 \%$ penicillin-streptomycin at $37{ }^{\circ} \mathrm{C}$ in a humidified environment of $5 \% \mathrm{CO}_{2}$. Then the harvested cells were seeded in a glass bottom dish at a suitable density and culture for $24 \mathrm{~h}$. The cells were then incubated with fresh medium containing P1b/2a/3 $(10 \mu \mathrm{M})$ for $2 \mathrm{~h}$ and washed with PBS, following incubated with LysoTracker Red (LTR) $(1 \mu \mathrm{M})$ for $30 \mathrm{~min}$ and washed with PBS. After that, cells were imaged by CLSM (Zeiss 880). Excitation wavelength: $405 \mathrm{~nm}$ (P1b/2a/3) and $514 \mathrm{~nm}$ (LTR); emission filter: 450-650 nm (P1b/2a/3) and 550-735 nm (LysoTracker Red).

\section{Photostability of P1b/2a/3}

Fluorescent images were continuously collected using CLSM (Zeiss 880) for 50 scans and then statistically analyzed using image processing software. The change in the fluorescence intensity of $\mathrm{P} \mathbf{1 b} / \mathbf{2} \mathbf{a} / \mathbf{3}$ and LTR was obtained and compared.

\section{Procedures for Gold Enrichment and Recovery}

Gold extraction with different dosages of $\mathrm{P} 1 \mathrm{e} / \mathbf{2 a} / \mathbf{3}$ : Into $2 \mathrm{~mL}$ aqueous solution of $\mathrm{Au}^{3+}$ with a concentration of $100 \mathrm{mg} / \mathrm{L}$ (the gold standard solution with the concentration of $1000 \mathrm{mg} / \mathrm{L}$ was diluted with $1 \mathrm{M} \mathrm{HCl}$ solution to furnish the resultant solution) was added $0,0.2,0.5,1,2$, or $4 \mathrm{mg}$ solid powder of $\mathrm{P} 1 \mathrm{e} / \mathbf{2} \mathbf{a} / \mathbf{3}$. After the mixtures were stirred at room temperature for $1 \mathrm{~h}$, the suspensions were centrifuged for $10 \mathrm{~min}$ with the spin rate of $8000 \mathrm{r} / \mathrm{min}$ and the solid was filtered by a filter membrane with an aperture of $0.22 \mu \mathrm{m}$. The remaining concentration of $\mathrm{Au}^{3+}$ in the supernatant was then measured by ICP-OES. The extraction or enrichment efficiency $(\eta)$ of polymers was calculated by the equation of $\eta=\left(\left[\mathrm{M}^{\mathrm{n}+}\right] 0^{-}\right.$ $\left.\left[\mathrm{M}^{\mathrm{n}+}\right]\right) /\left[\mathrm{M}^{\mathrm{n}+}\right]_{0} \times 100 \%$, where $\left[\mathrm{M}^{\mathrm{n}+}\right]_{0}$ is the initial concentration of metal ion, and $\left[\mathrm{M}^{\mathrm{n}+}\right]$ is the remaining concentration of metal ion. The extraction capacity of polymers was calculated to be $V_{M} \times\left[M^{n+}\right]_{0} \times \eta / m_{p}$, where $V_{M}$ is the volume of the gold solution, $m_{p}$ is the weight of the polymer.

Time-dependent gold extraction: Into $2 \mathrm{~mL}$ aqueous solution of $\mathrm{Au}^{3+}(100 \mathrm{mg} / \mathrm{L})$ were added $4 \mathrm{mg}$ solid powders of $\mathbf{P 1 e} / \mathbf{2 a} / \mathbf{3}$. After the mixtures were stirred at room temperature for 5, 10, 30, 40, and 60 min, respectively, the suspensions were centrifuged for $10 \mathrm{~min}$ with a spin rate of $8000 \mathrm{r} / \mathrm{min}$ and the 
solid was filtered by a filter membrane with an aperture of $0.22 \mu \mathrm{m}$. The remaining concentration of $\mathrm{Au}^{3+}$ in the supernatant was then measured by ICP-OES to calculate the extraction efficiency.

Selectivity test with single metal ion: Into $2 \mathrm{~mL}$ aqueous solutions of $\mathrm{Mn}^{2+}, \mathrm{Cu}^{2+}, \mathrm{Co}^{2+}, \mathrm{Ni}^{2+}, \mathrm{Cd}^{2+}, \mathrm{Au}^{3+}$, $\mathrm{Pd}^{2+}, \mathrm{Ru}^{3+}, \mathrm{Na}^{+}, \mathrm{Ca}^{2+}, \mathrm{Mg}^{2+}\left(\left[\mathrm{M}^{\mathrm{n}+}\right]=100 \mathrm{mg} / \mathrm{L}\right)$ was added $4 \mathrm{mg}$ solid powder of $\mathrm{P} \mathbf{1 e} / \mathbf{2 a} / \mathbf{3}$, respectively. After the mixtures were stirred at room temperature for $1 \mathrm{~h}$, the suspensions were centrifuged for $10 \mathrm{~min}$ with a spin rate of $8000 \mathrm{r} / \mathrm{min}$ and the solid was filtered by a filter membrane with an aperture of 0.22 $\mu \mathrm{m}$. The remaining concentration of metal ions in the supernatant was then measured by ICP-OES to calculate the extraction efficiency.

Selectivity test with mixed metal ions : Into $2 \mathrm{~mL}$ aqueous solution including $\mathrm{Mn}^{2+}, \mathrm{Cu}^{2+}, \mathrm{Co}^{2+}, \mathrm{Ni}^{2+}$, $\mathrm{Cd}^{2+}, \mathrm{Au}^{3+}, \mathrm{Pd}^{2+}, \mathrm{Ru}^{3+}, \mathrm{Na}^{+}, \mathrm{Ca}^{2+}, \mathrm{Mg}^{2+}\left(\left[\mathrm{M}^{\mathrm{n}+}\right]=100 \mathrm{mg} / \mathrm{L}\right.$ for each metal ion) was added $4 \mathrm{mg}$ solid powder of $\mathrm{P} \mathbf{1} \mathbf{e} / \mathbf{2} \mathbf{a} / \mathbf{3}$. After the mixtures were stirred at room temperature for $1 \mathrm{~h}$, the suspensions were centrifuged for $10 \mathrm{~min}$ with a spin rate of $8000 \mathrm{r} / \mathrm{min}$ and the solid was filtered by a filter membrane with an aperture of $0.22 \mu \mathrm{m}$. The remaining concentration of metal ions in the supernatant was then measured by ICP-OES to calculate the extraction efficiency.

Gold recovery by pyrolysis. Into $200 \mathrm{~mL}$ of $\mathrm{Au}^{3+}$ aqueous solution $\left(\left[\mathrm{Au}^{3+}\right]=1000 \mathrm{mg} / \mathrm{L}\right)$ was added $300 \mathrm{mg} \mathrm{P} \mathbf{1 e} / \mathbf{2 a} / \mathbf{3}$. After the mixture was stirred at room temperature for $1 \mathrm{~h}$, the suspension was centrifuged for $10 \mathrm{~min}$ with a spin rate of $8000 \mathrm{r} / \mathrm{min}$. After the supernatant was removed, the solid was dried at $60{ }^{\circ} \mathrm{C}$ under vacuum oven overnight to afford $450 \mathrm{mg}$ black solid powder. The solid was then pyrolyzed in air at $1000{ }^{\circ} \mathrm{C}$ for $4 \mathrm{~h}$ with a heating rate of $10^{\circ} \mathrm{C} / \mathrm{min}$ to afford $115 \mathrm{mg}$ yellow product with metallic luster. The gold content of the sample was determined by ICP-OES measurement to be 96.61 wt $\%$. 
Scheme S1. Proposed mechanism of a $\mathrm{Cu}(\mathrm{I})$-catalyzed three-component reaction of alkyne, sulfonyl azide, and $N, N$-dimethylformamide dimethyl acetal.

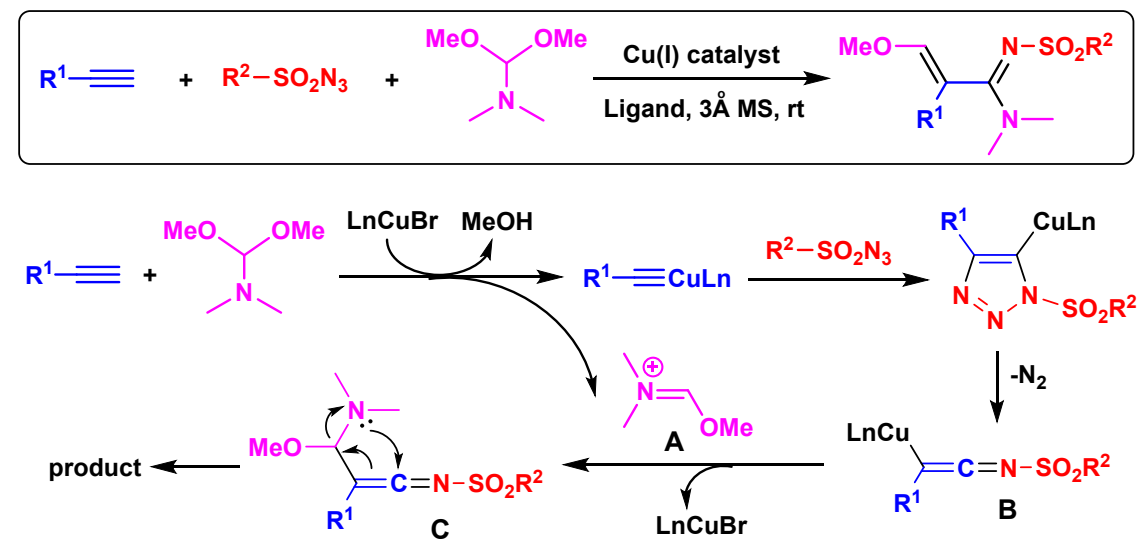

Table S1. Effect of solvent on the polymerization of $\mathbf{1 a}, \mathbf{2 a}$ and $\mathbf{3}^{a}$

\begin{tabular}{cccccc} 
entry & solvent & yield (\%) & $M_{\mathrm{n}}{ }^{\mathrm{b}}$ & $M_{\mathrm{w}}{ }^{\mathrm{b}}$ & $\mathrm{PDI}^{\mathrm{b}}$ \\
1 & DCM & 90 & 25300 & 41000 & 1.6 \\
2 & DCE & 83 & 16400 & 28300 & 1.7 \\
3 & THF & 67 & 8000 & 10300 & 1.3 \\
4 & toluene & trace & & & \\
\hline
\end{tabular}

${ }^{a}$ Carried out at room temperature under $\mathrm{N}_{2}$ for $1 \mathrm{~h},[\mathbf{1 a}]=[\mathbf{2 a}]=0.1 \mathrm{M},[\mathbf{3}]=0.2 \mathrm{M}, \mathrm{CuBr}(20 \mathrm{~mol} \%)$, dppe (20 mol\%), $3 \AA$ MS (40 mg). ${ }^{b}$ Estimated by GPC in DMF on the basis of a linear polystyrene calibration. PDI $=M_{\mathrm{w}} / M_{\mathrm{n}}$. Abbreviation: dppe $=1,2$-bis(diphenylphosphino)ethane.
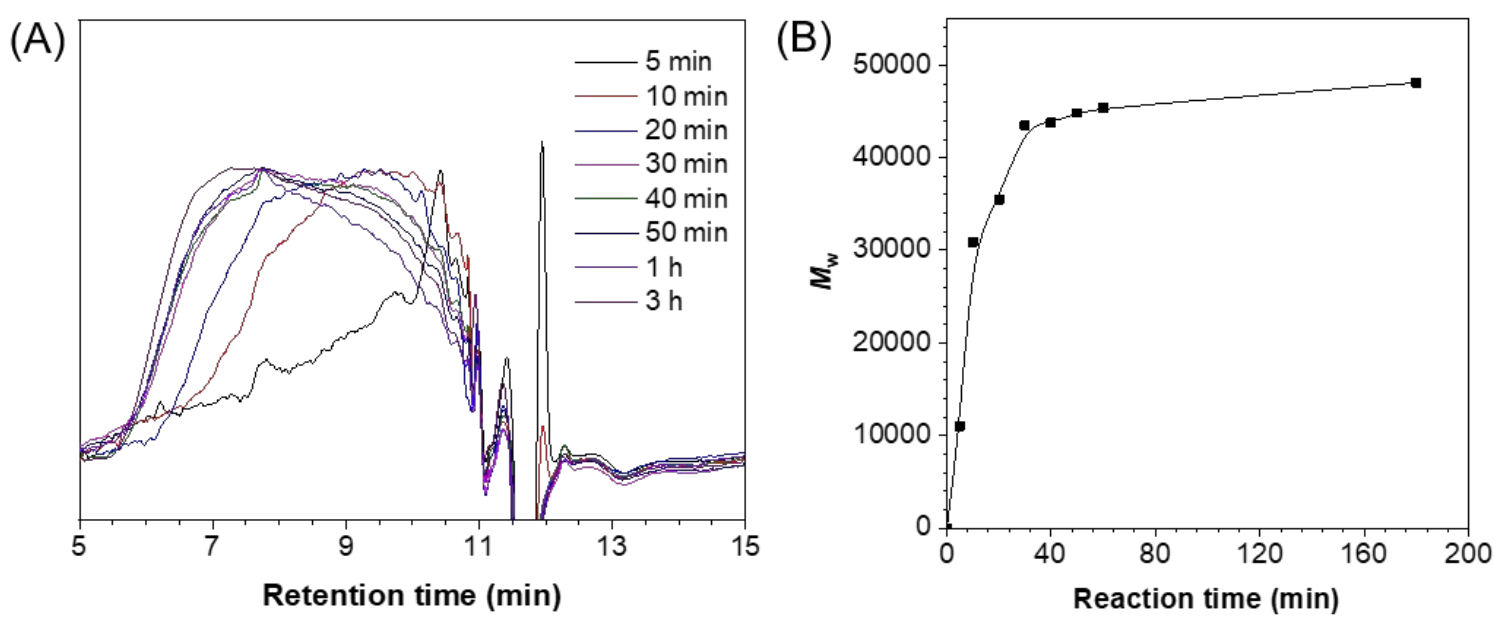

Figure S1. (A) Normalized GPC curves of the polymers obtained at different reaction time. (B) Change in the $M_{\mathrm{w}}$ of the polymers obtained at different polymerization time. 
Scheme S2. Synthetic routes to monomer le
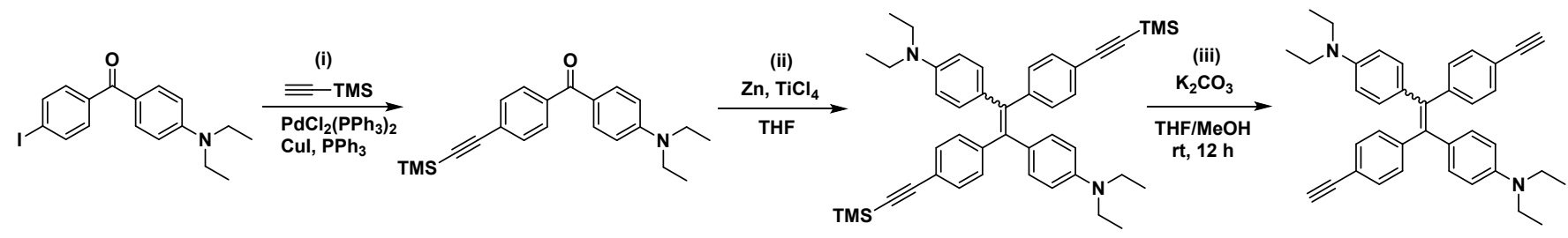

Scheme S3. Synthetic route to model compound 5
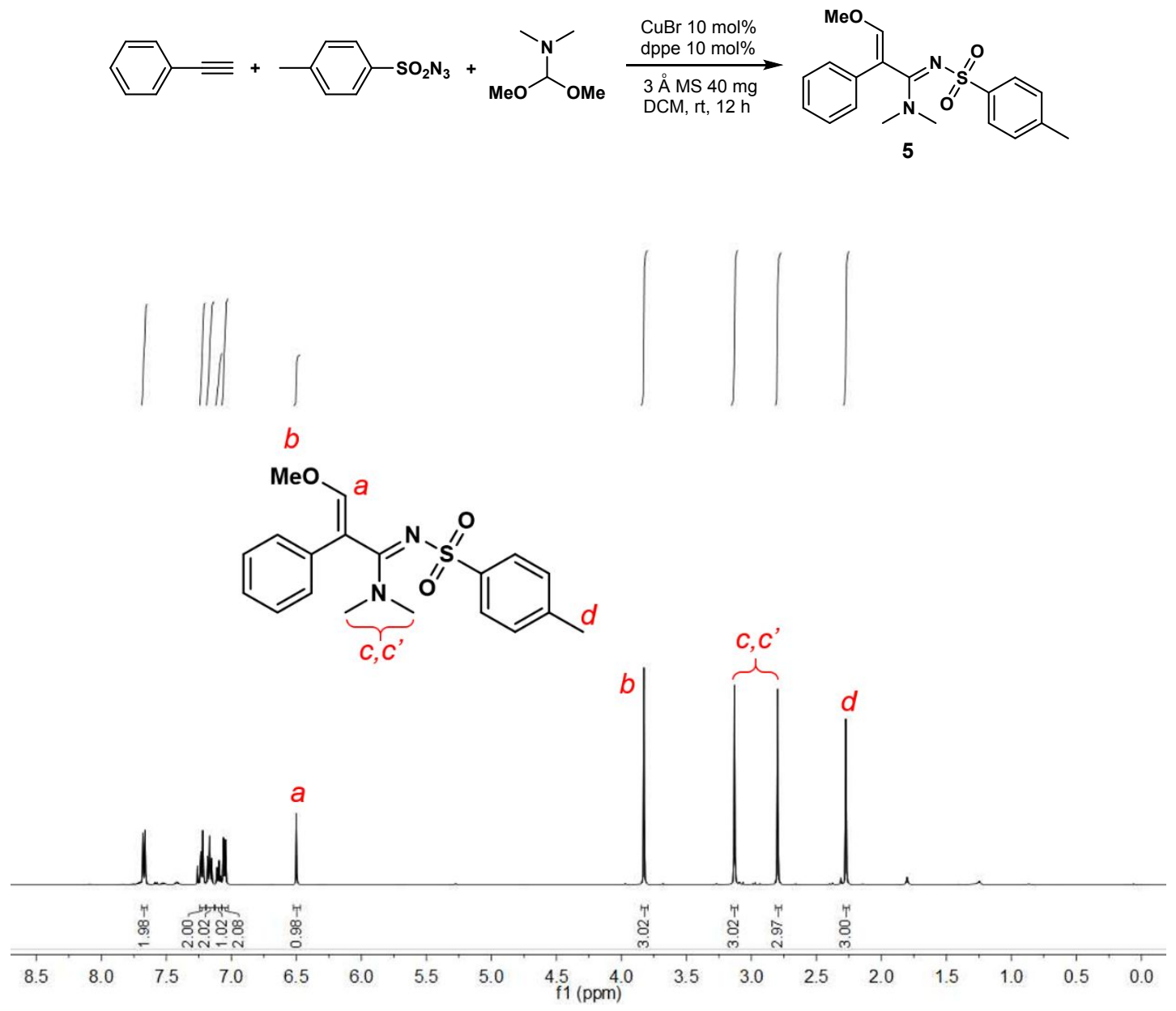

Figure S2. ${ }^{1} \mathrm{H}$ NMR spectrum of model compound 5 in $\mathrm{CDCl}_{3}$

10 

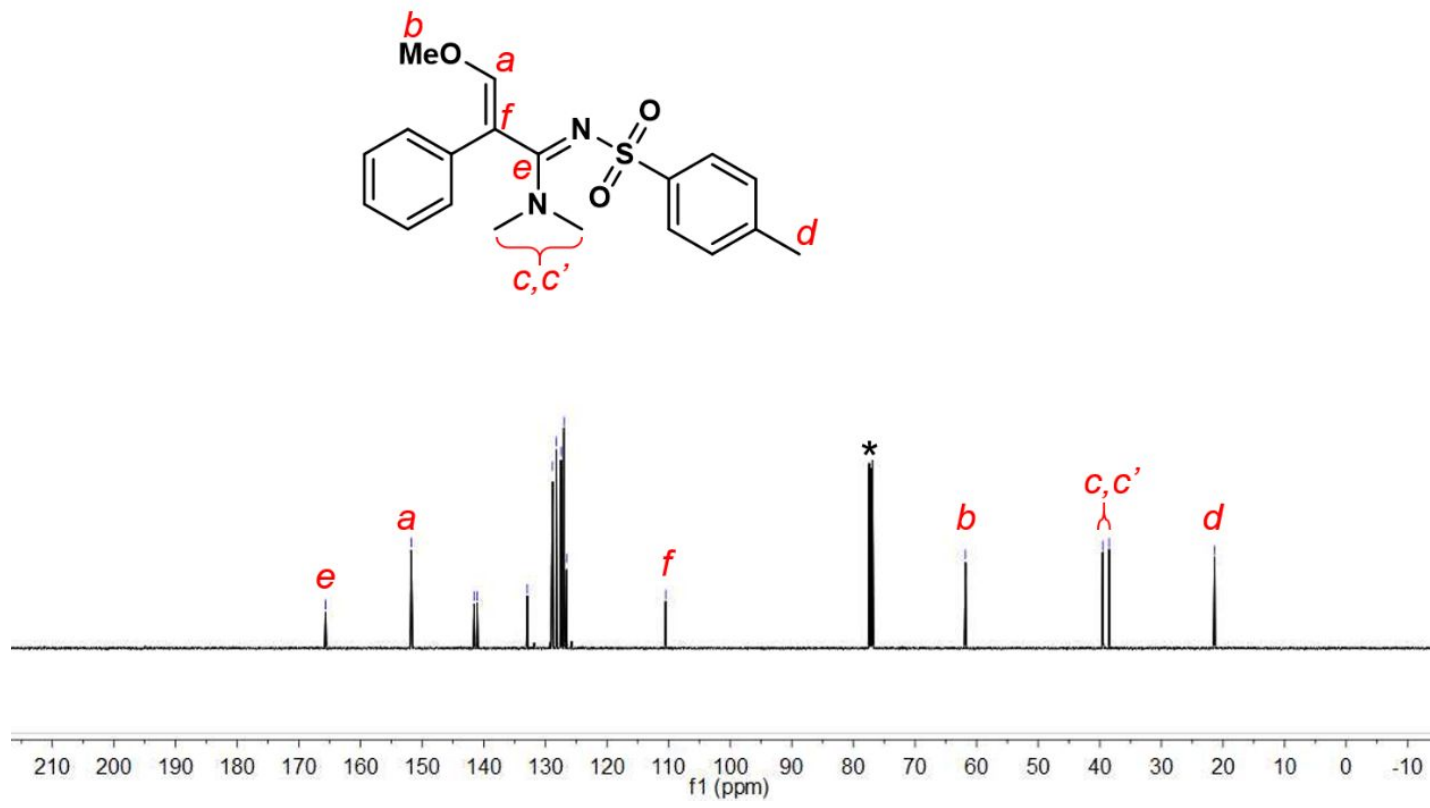

Figure S3. ${ }^{13} \mathrm{C}$ NMR spectrum of model compound 5 in $\mathrm{CDCl}_{3}$

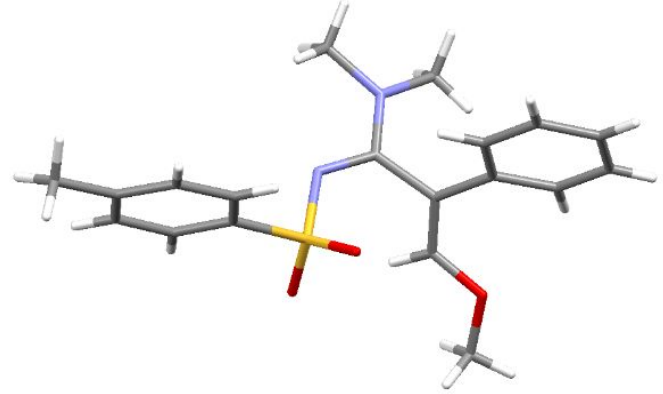

Figure S4. X-ray crystal structure of model compound 5 (CCDC number: 986538). 
(A)

Crude reaction mixture

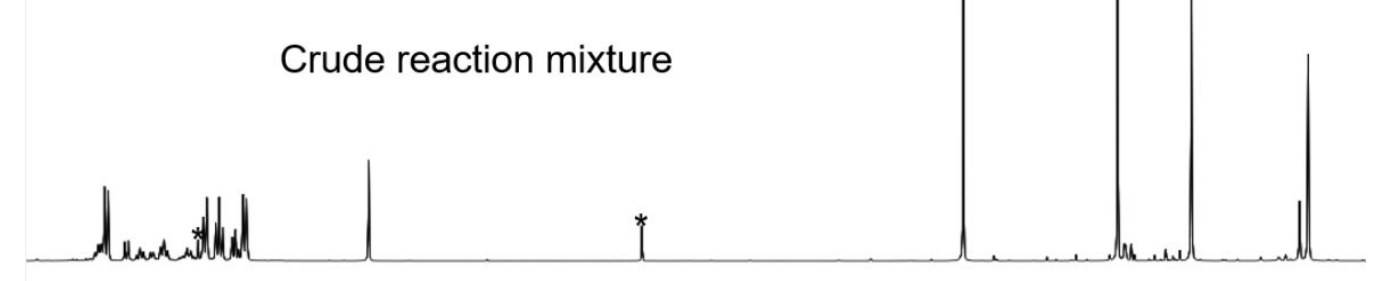

(B)

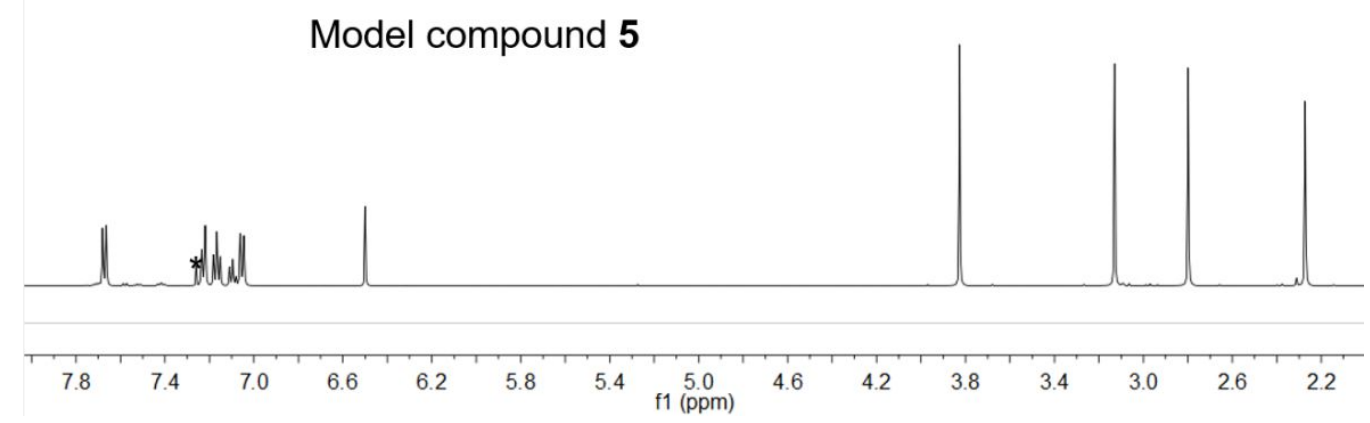

Figure S5. ${ }^{1} \mathrm{H}$ NMR spectra of (A) crude reaction mixture of the model reaction of phenylacetylene, tosyl azide and $\mathbf{3}$ and (B) the pure reaction product (compound 5) in $\mathrm{CDCl}_{3}$.

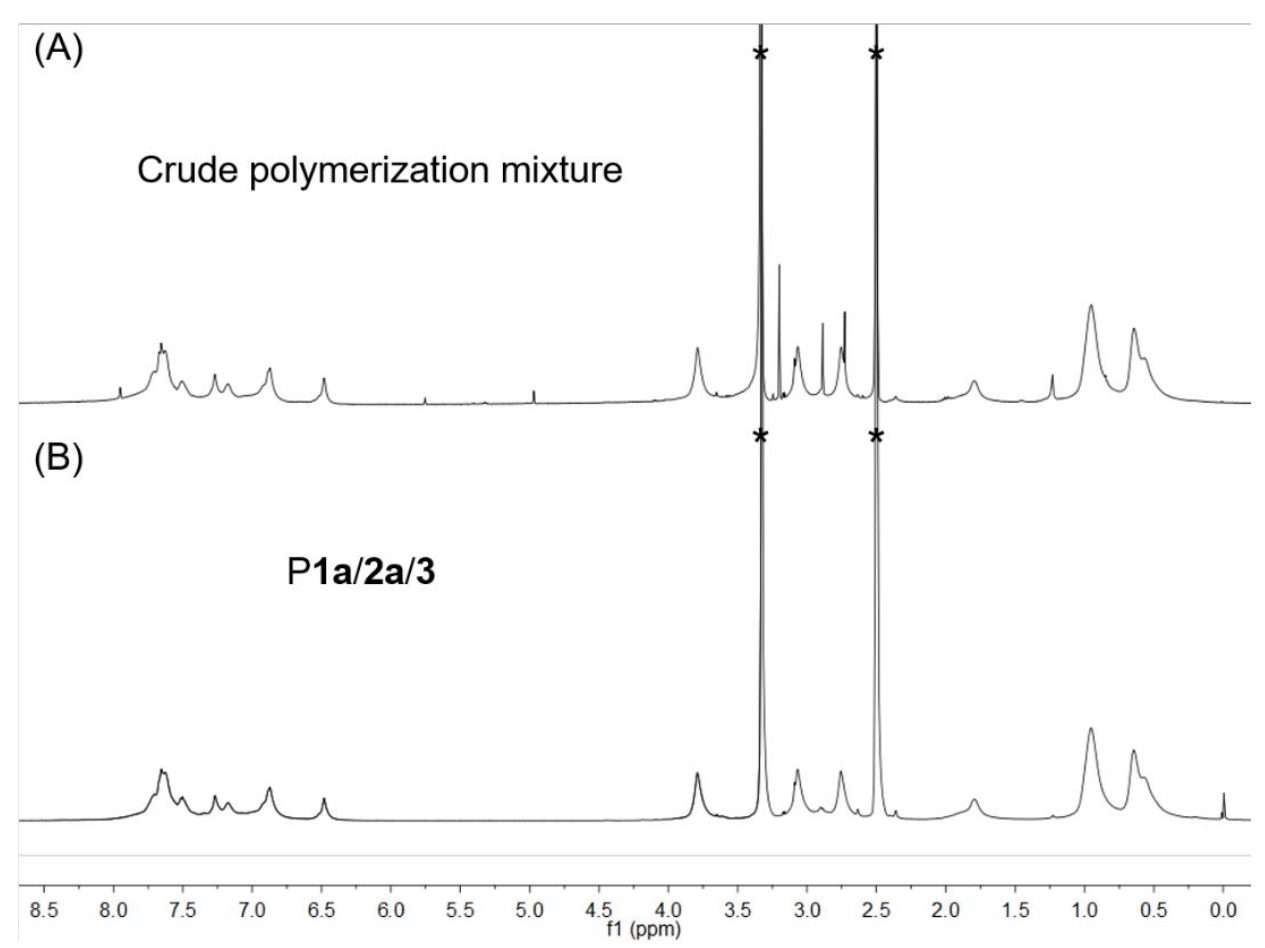

Figure S6. ${ }^{1} \mathrm{H}$ NMR spectra of (A) crude reaction mixture of the polymerization of 1a, 2a and $\mathbf{3}$ and (B) the pure polymeric product $(\mathrm{P} \mathbf{1} \mathbf{a} / \mathbf{2} \mathbf{a} / \mathbf{3})$ in $\mathrm{DMSO}-d_{6}$. 


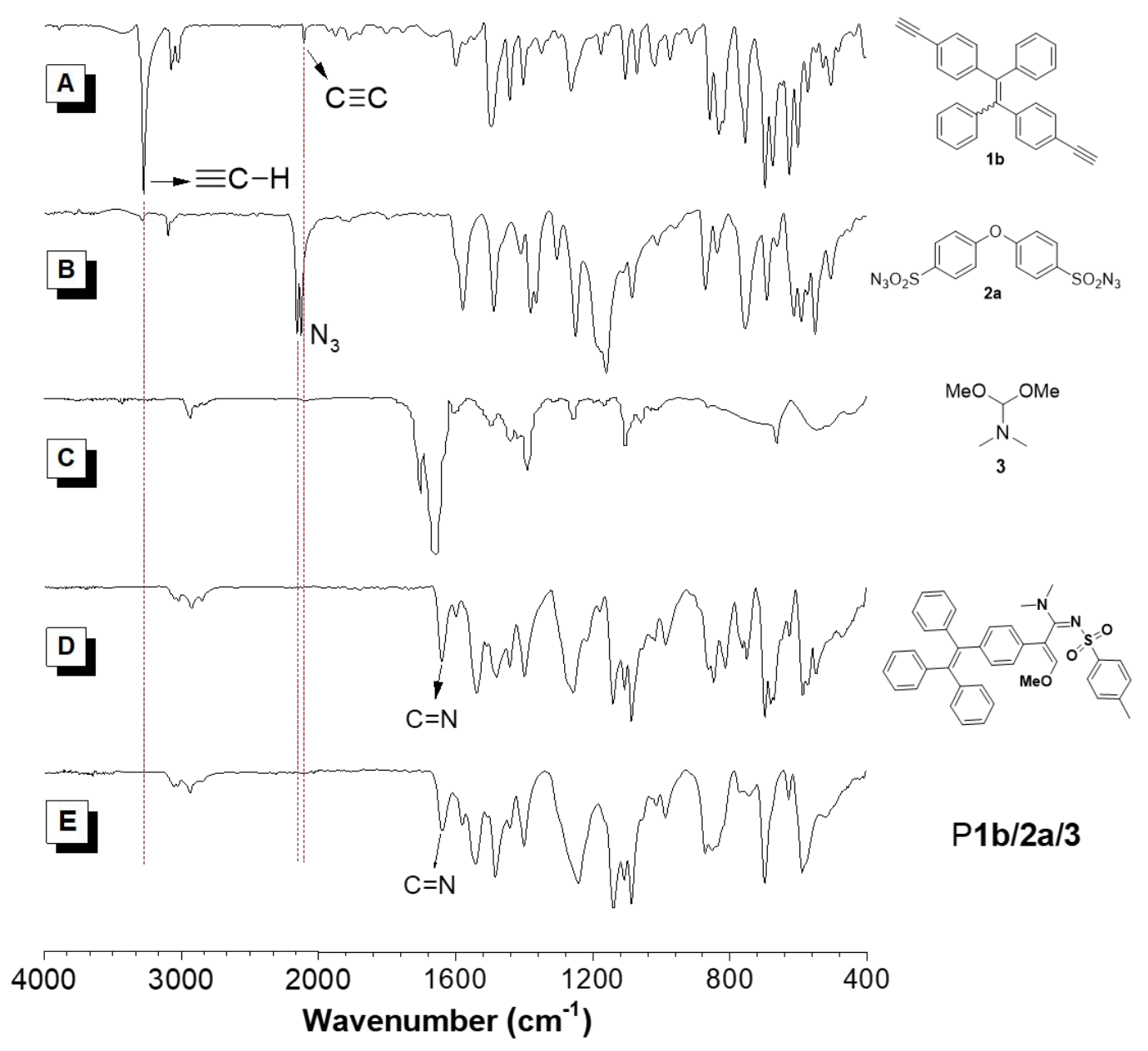

Figure S7. IR spectra of (A) 1b, (B) 2a, (C) 3, (D) model compound 4, and (E) P1b/2a/3. 

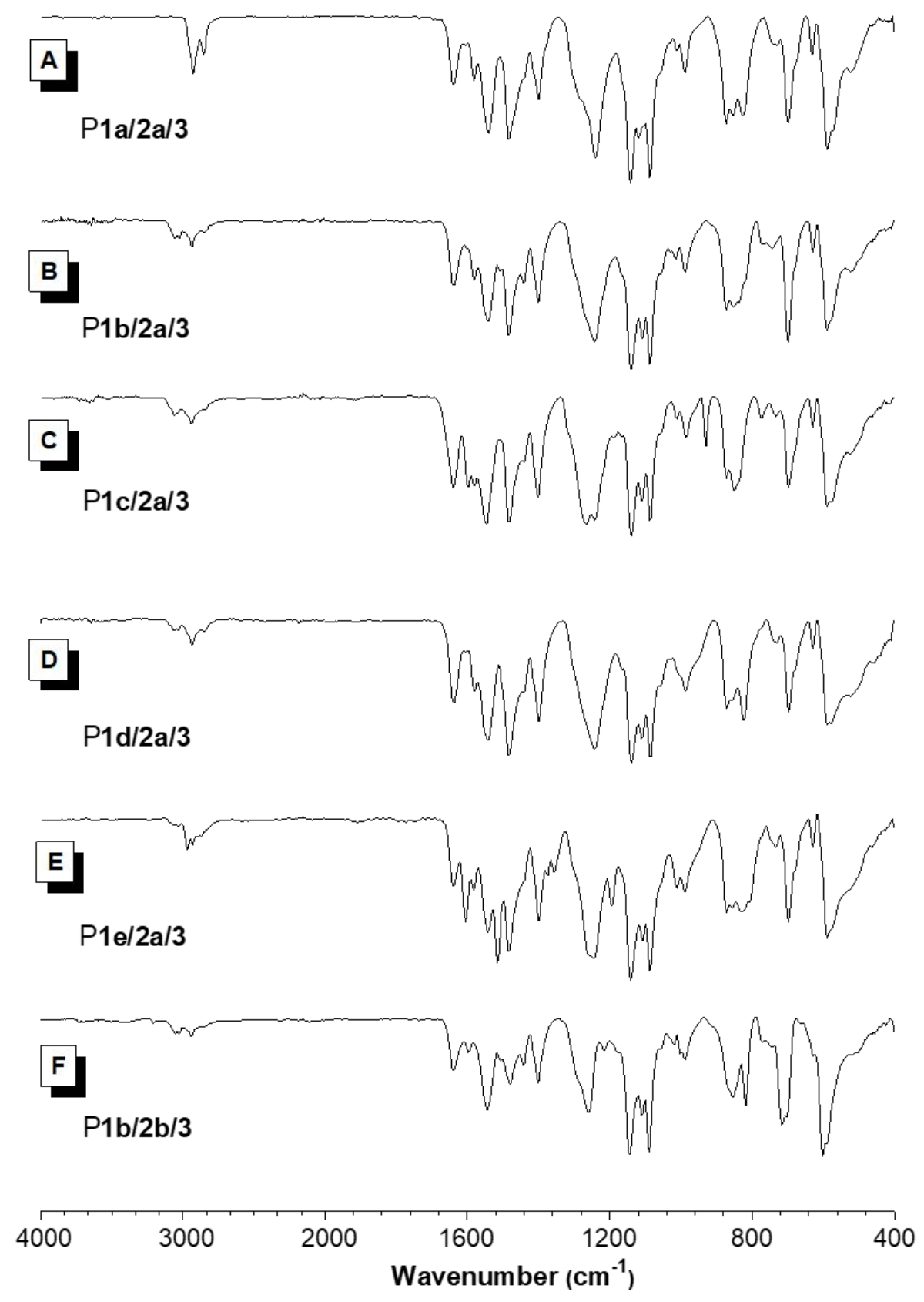

Figure S8. IR spectra of (A) P1a/2a/3, (B) P1b/2a/3, (C) P1c/2a/3, (D) P1d/2a/3, (E) P1e/2a/3, and (F) $\mathrm{P} \mathbf{1 b} / \mathbf{2 b} / \mathbf{3}$. 


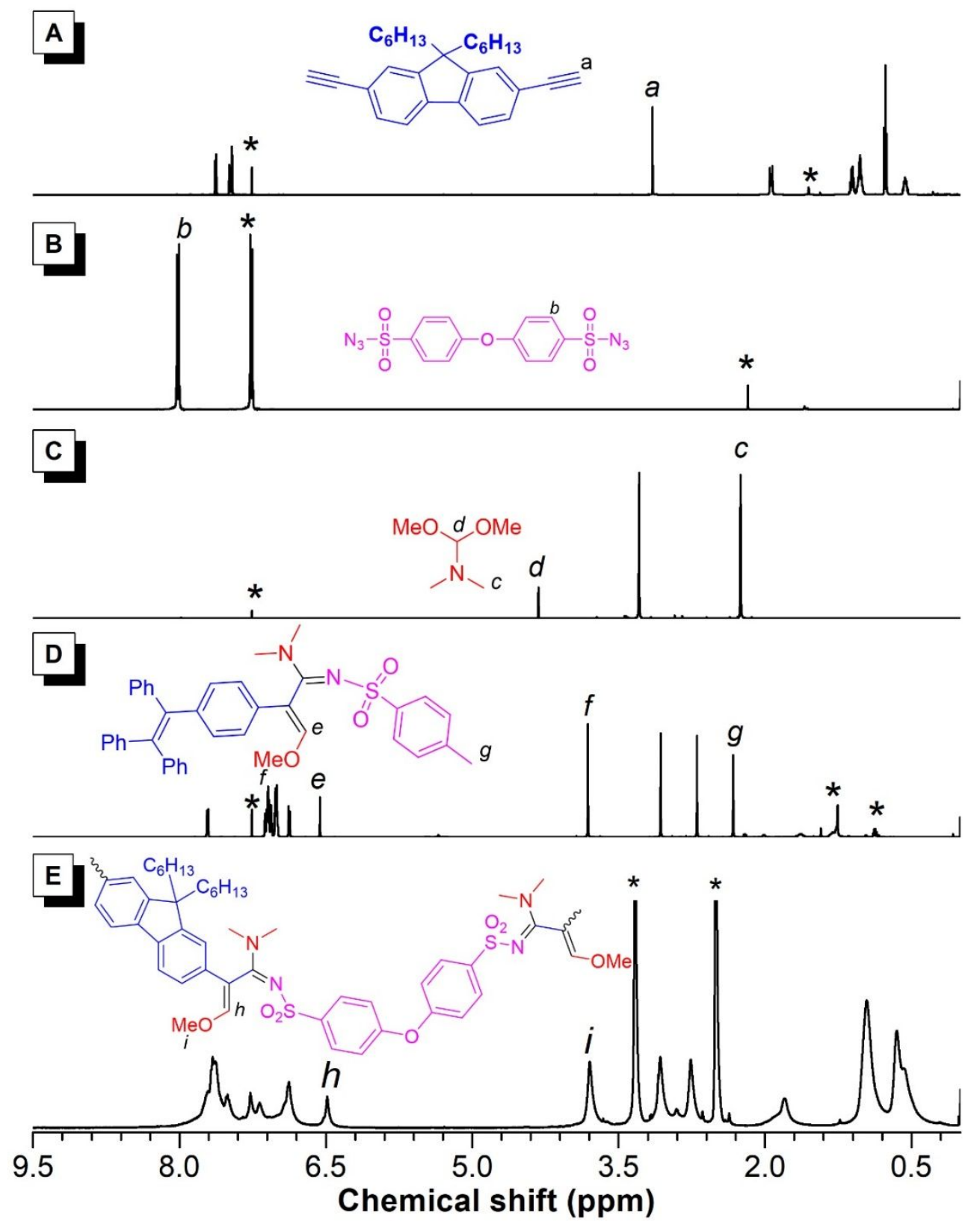

Figure S9. ${ }^{1} \mathrm{H}$ NMR spectra of (A) 1a, (B) 2a, (C) 3, and (D) model compound 4 in $\mathrm{CDCl}_{3}$ and (E) $\mathrm{P} \mathbf{1 a} / \mathbf{2 a} / \mathbf{3}$ in DMSO- $d_{6}$. 


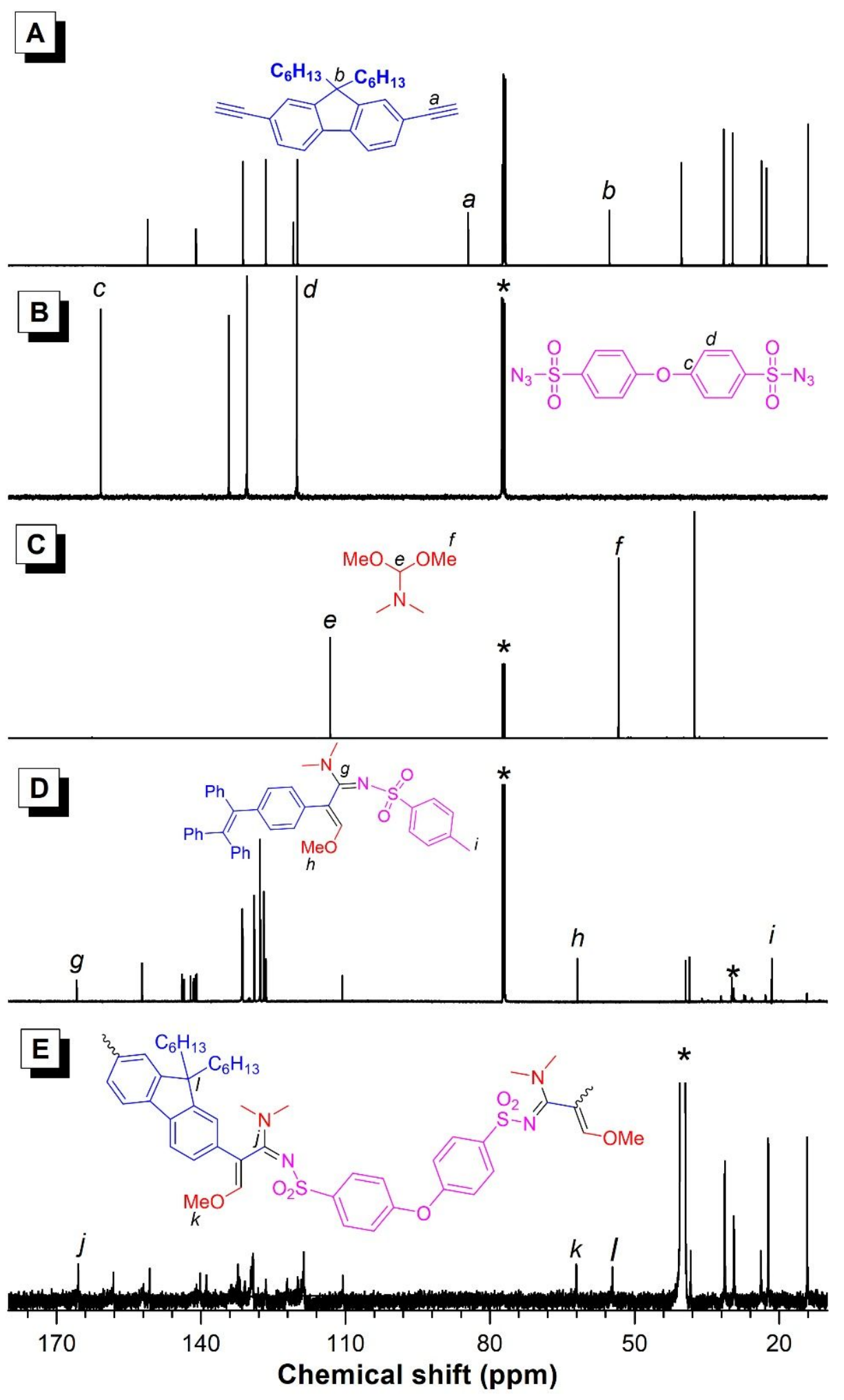

Figure S10. ${ }^{13} \mathrm{C}$ NMR spectra of (A) 1a, (B) 2a, (C) 3, and (D) model compound $\mathbf{4}$ in $\mathrm{CDCl}_{3}$ and (E) $\mathrm{P} \mathbf{1} \mathbf{a} / \mathbf{2} \mathbf{a} / \mathbf{3}$ in DMSO- $d_{6}$. 


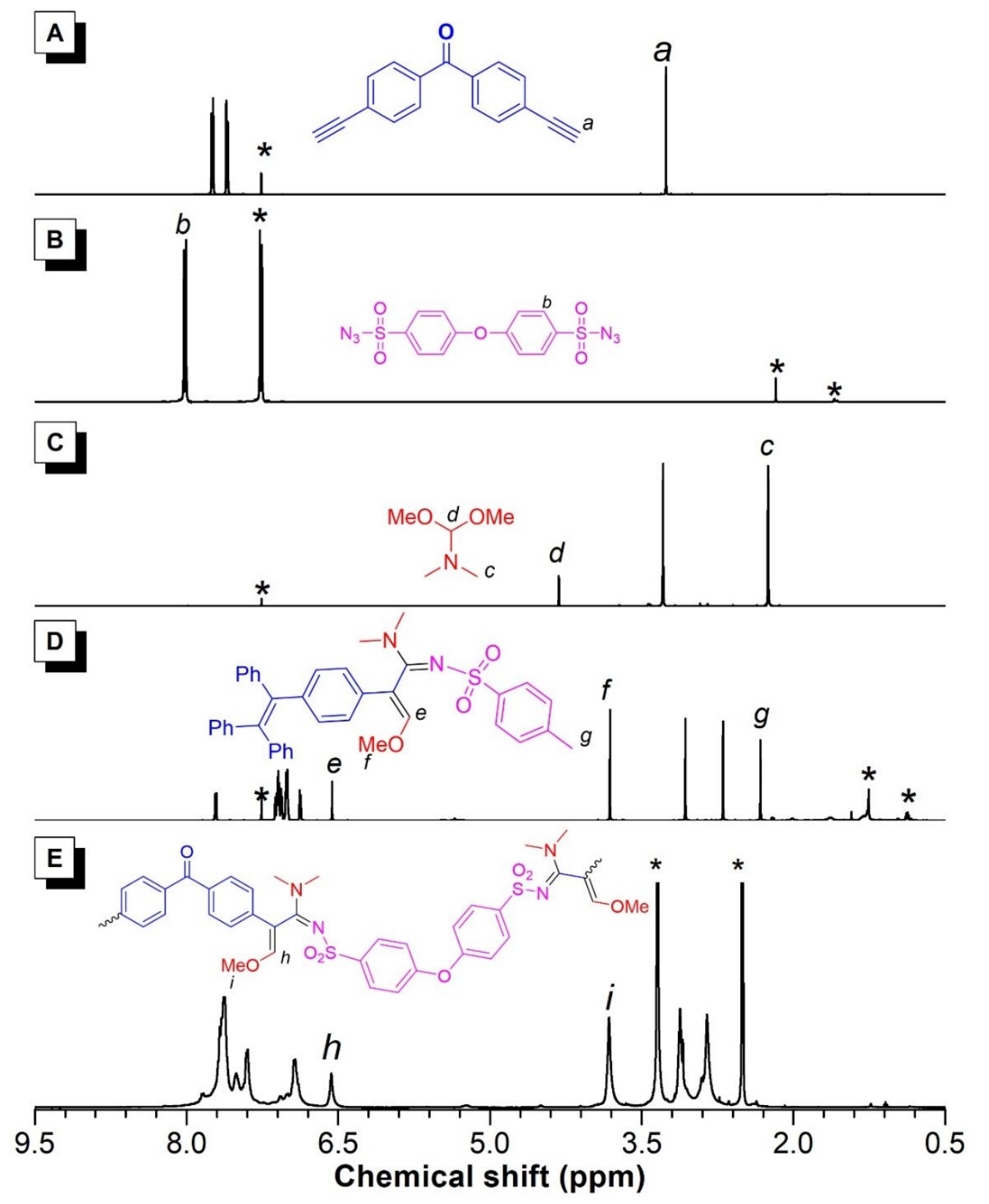

Figure S11. ${ }^{1} \mathrm{H}$ NMR spectra of (A) 1c, (B) 2a, (C) 3, and (D) model compound 4 in $\mathrm{CDCl}_{3}$ and (E) $\mathrm{P} \mathbf{1 c} / \mathbf{2 a} / \mathbf{3}$ in DMSO- $d_{6}$. 


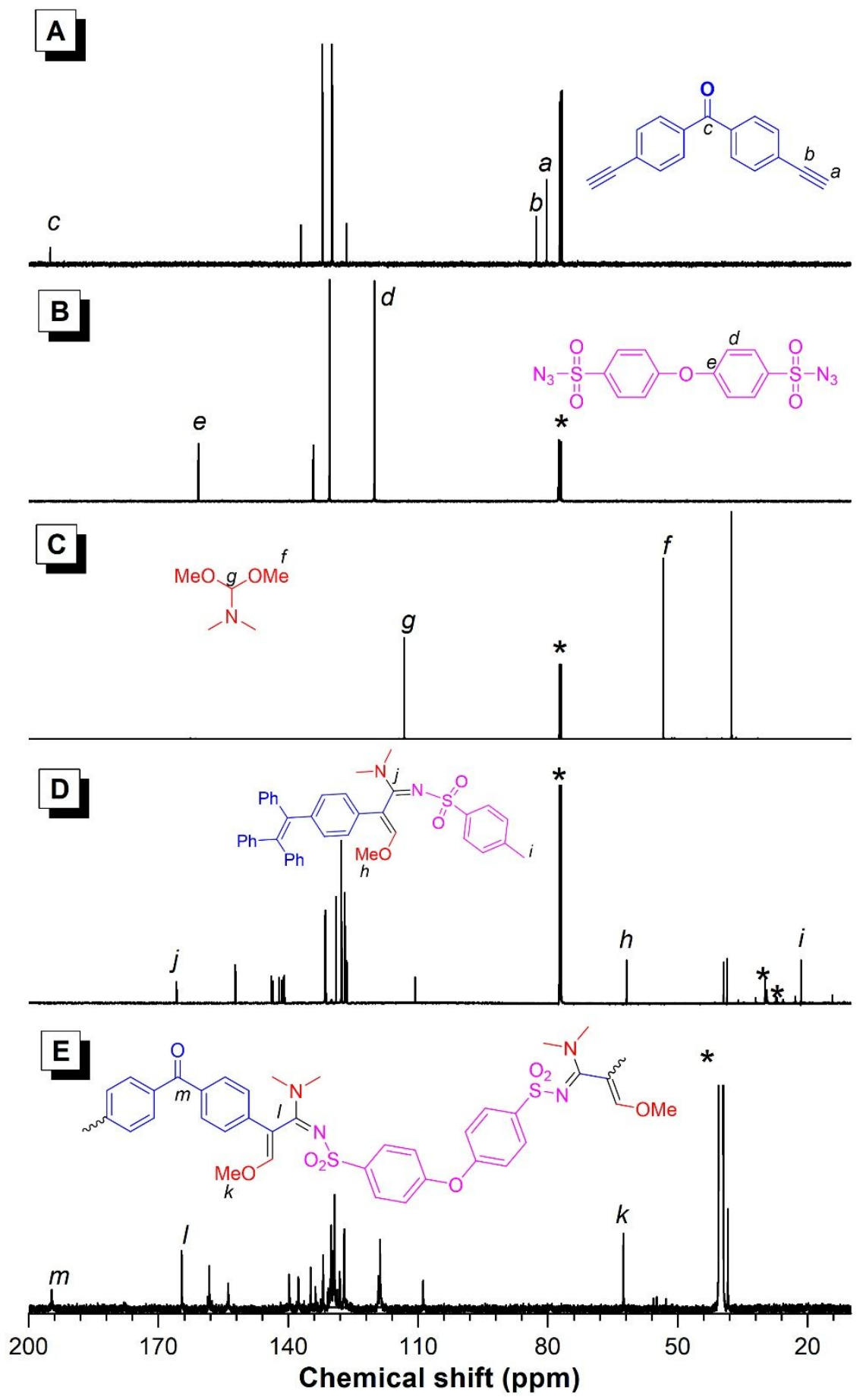

Figure S12. ${ }^{13} \mathrm{C}$ NMR spectra of (A) 1c, (B) 2a, (C) 3, and (D) model compound 4 in $\mathrm{CDCl}_{3}$ and (E) $\mathrm{P} \mathbf{1 c} / \mathbf{2 a} / \mathbf{3}$ in DMSO- $d_{6}$. 


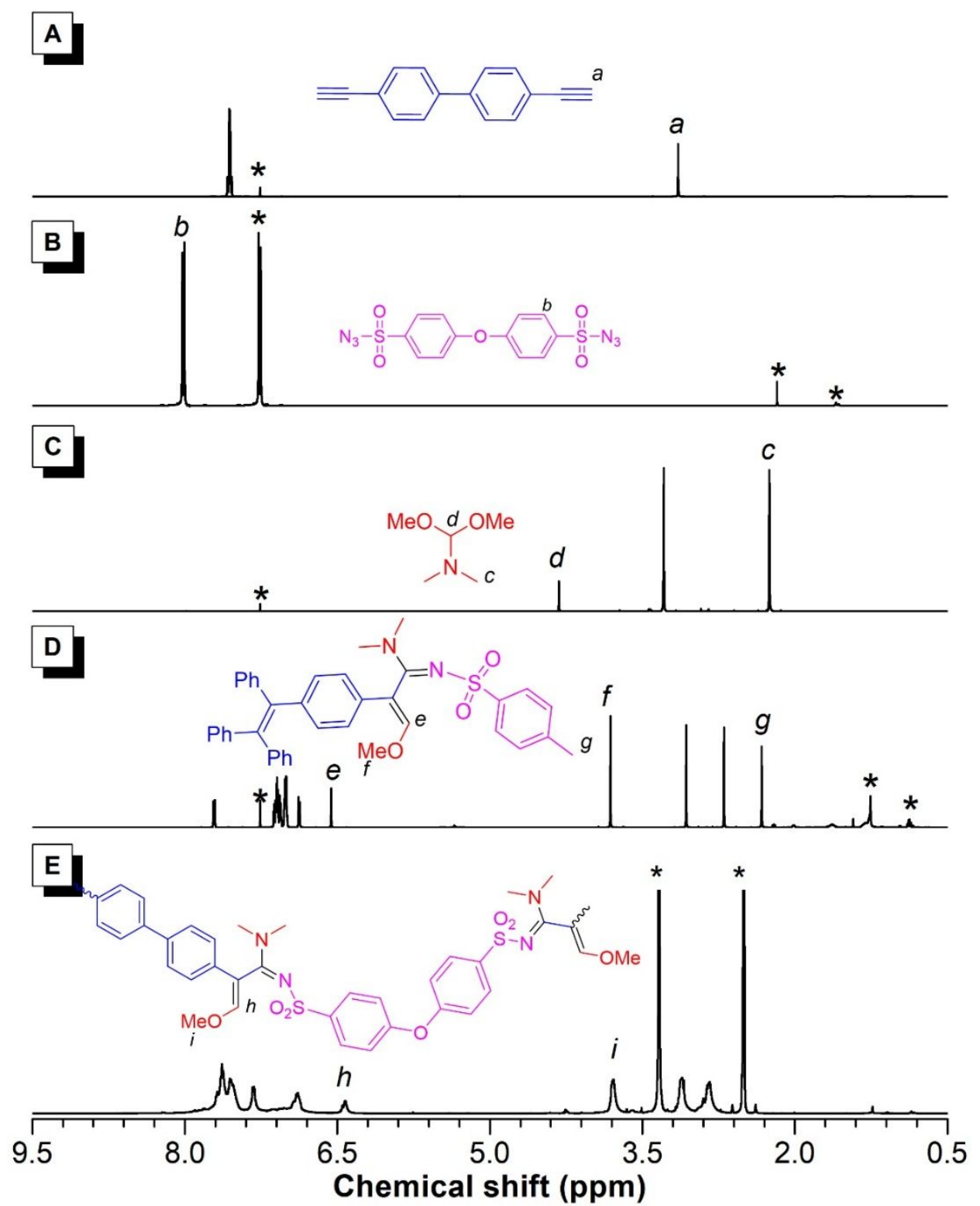

Figure S13. ${ }^{1} \mathrm{H}$ NMR spectra of (A) 1d, (B) 2a, (C) 3, and (D) model compound 4 in $\mathrm{CDCl}_{3}$ and (E) $\mathrm{P} \mathbf{1 d} / \mathbf{2 a} / \mathbf{3}$ in DMSO$-d_{6}$. 


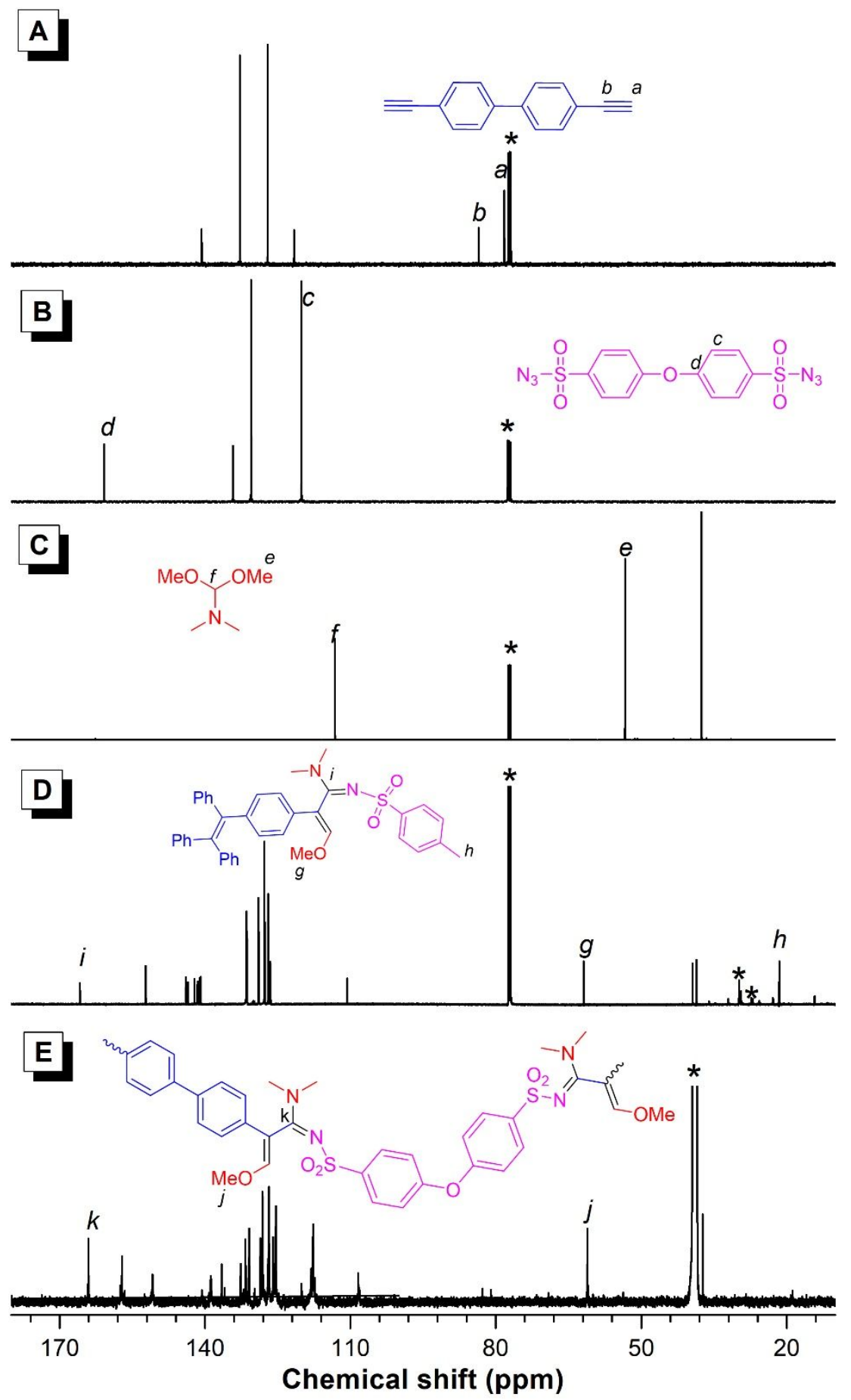

Figure S14. ${ }^{13} \mathrm{C}$ NMR spectra of (A) 1d, (B) 2a, (C) 3, and (D) model compound 4 in $\mathrm{CDCl}_{3}$ and (E) $\mathrm{P} \mathbf{1 d} / \mathbf{2} \mathbf{a} / \mathbf{3}$ in DMSO- $d_{6}$. 


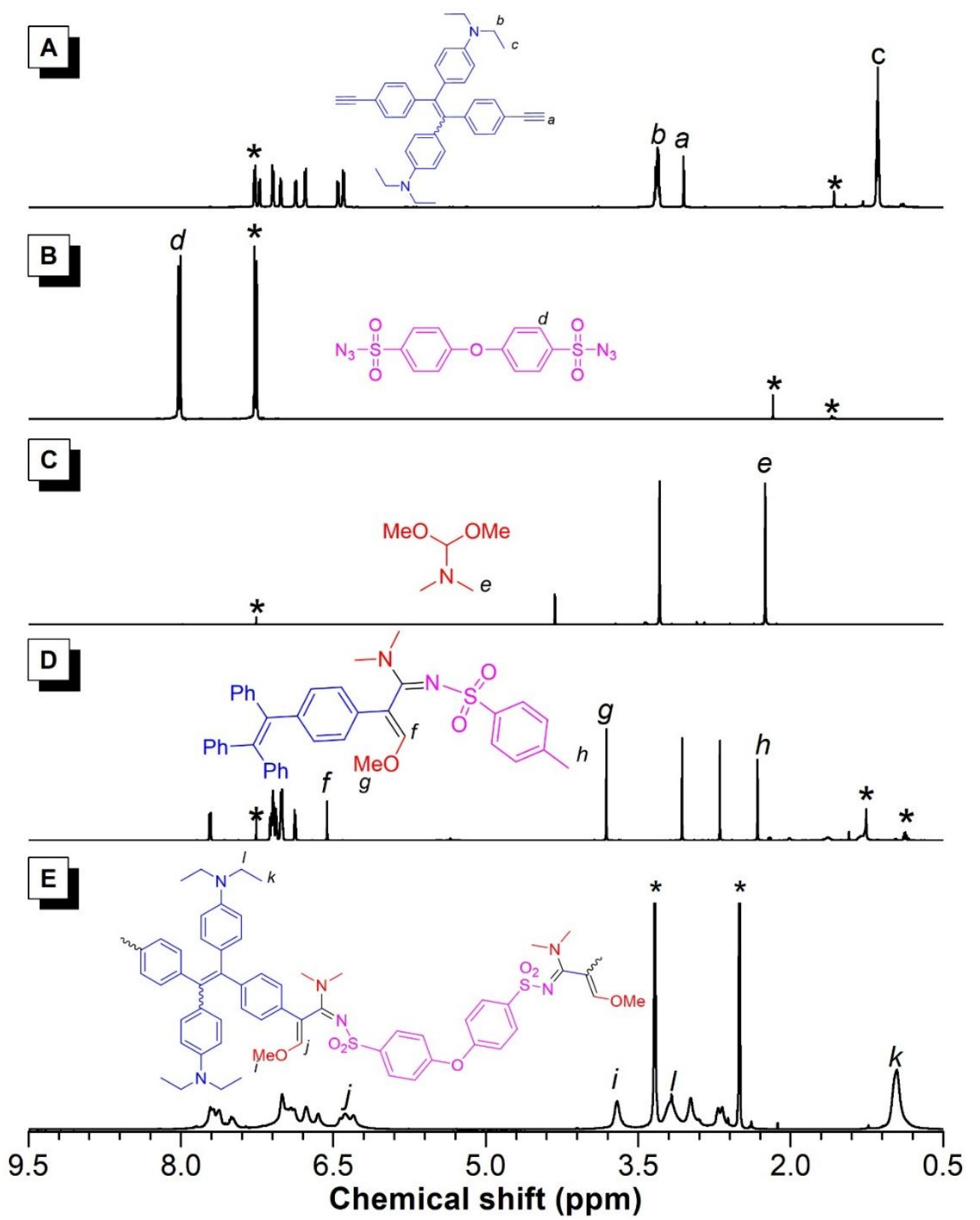

Figure S15. ${ }^{1} \mathrm{H}$ NMR spectra of (A) 1e, (B) 2a, (C) 3, and (D) model compound 4 in $\mathrm{CDCl}_{3}$ and (E) $\mathrm{P} \mathbf{1 e} / \mathbf{2} \mathbf{a} / \mathbf{3}$ in DMSO- $d_{6}$. 


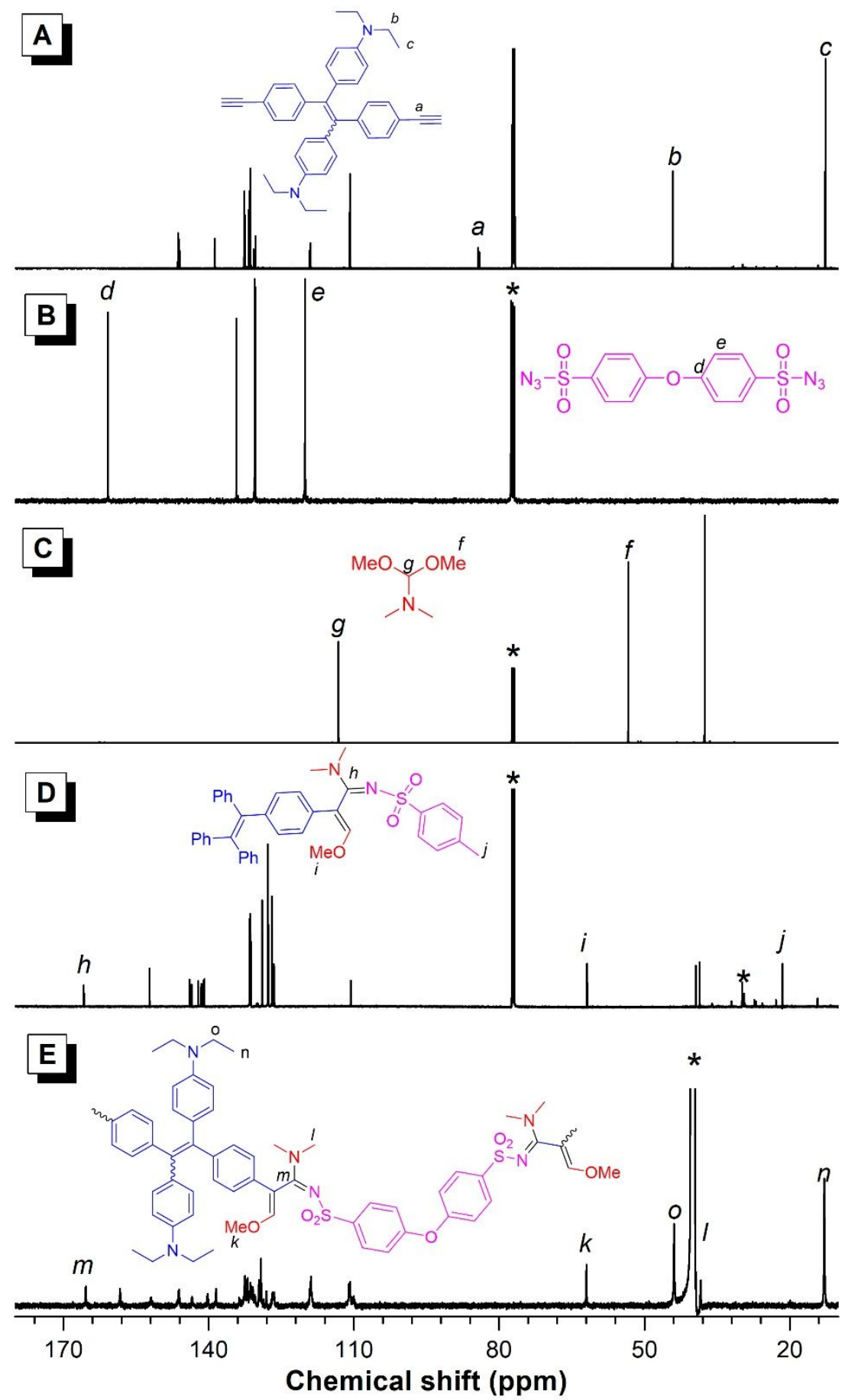

Figure S16. ${ }^{13} \mathrm{C}$ NMR spectra of (A) 1e, (B) 2a, (C) 3, and (D) model compound 4 in $\mathrm{CDCl}_{3}$ and (E) $\mathrm{P} \mathbf{1 e} / \mathbf{2 a} / \mathbf{3}$ in DMSO- $d_{6}$. 


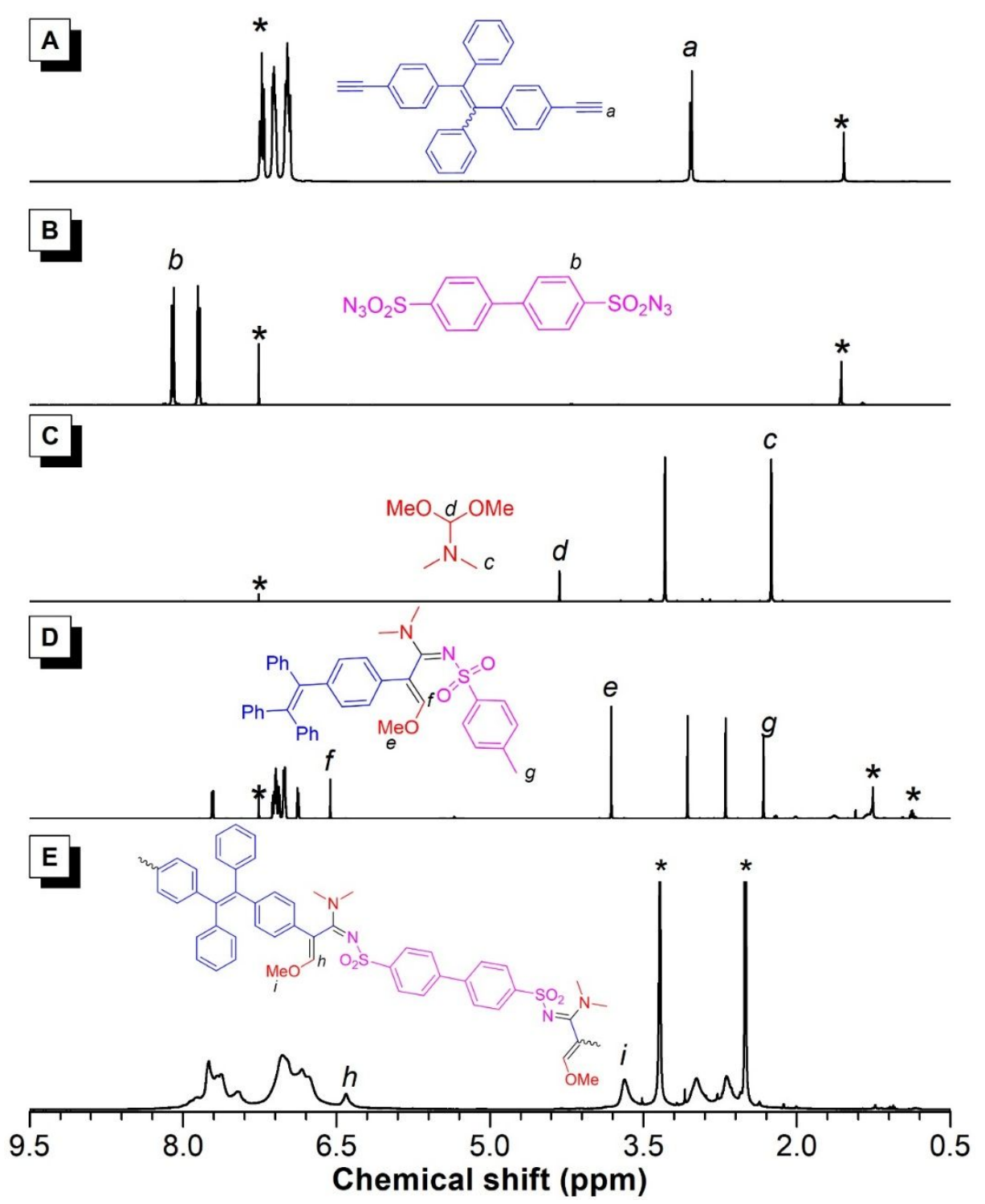

Figure S17. ${ }^{1} \mathrm{H}$ NMR spectra of (A) 1b, (B) 2b, (C) 3, and (D) model compound 4 in $\mathrm{CDCl}_{3}$ and (E) $\mathrm{P} \mathbf{1 b} / \mathbf{2 b} / \mathbf{3}$ in DMSO- $d_{6}$. 


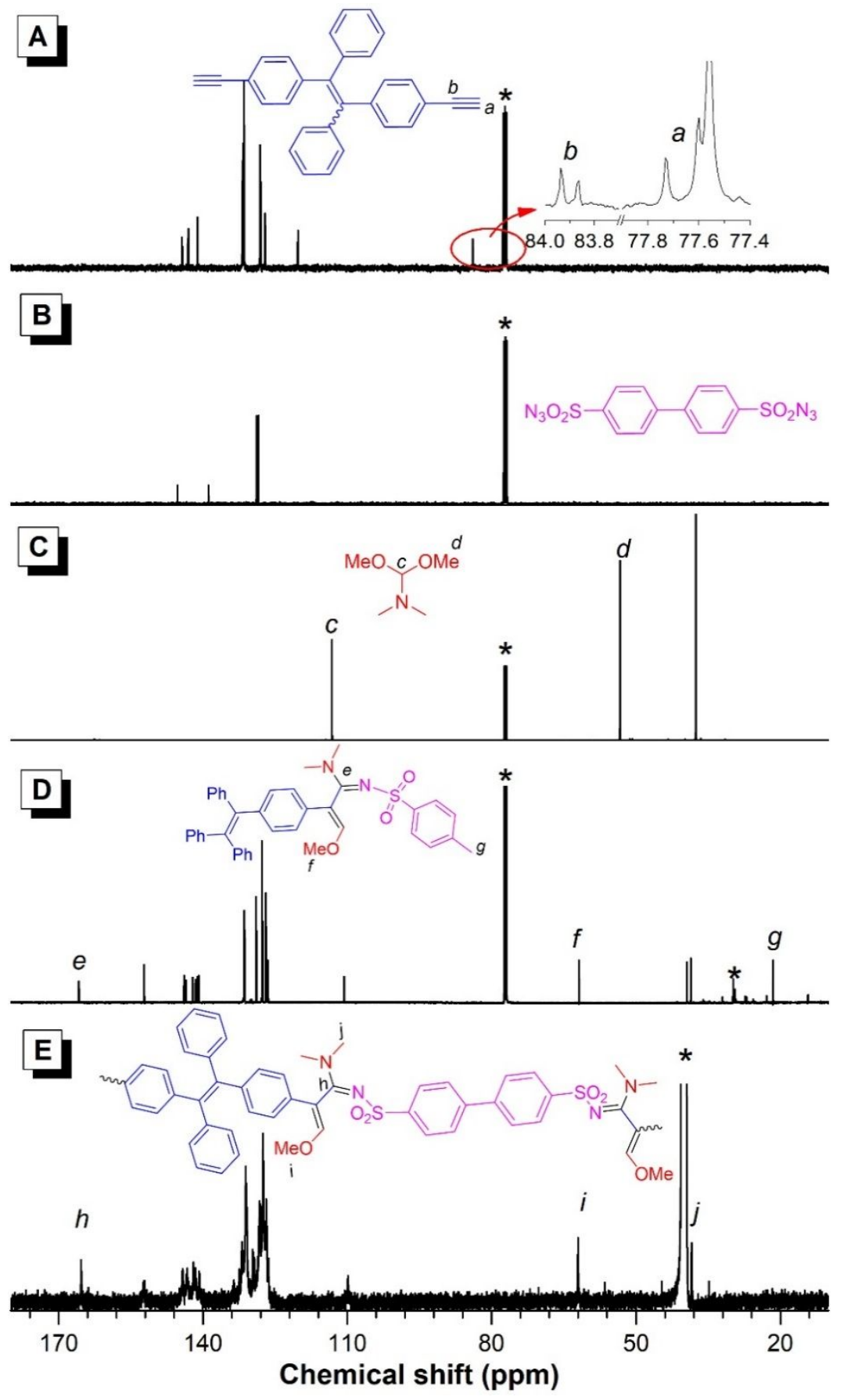

Figure S18. ${ }^{13} \mathrm{C}$ NMR spectra of (A) $\mathbf{1 b},(\mathrm{B}) \mathbf{2 b},(\mathrm{C}) \mathbf{3}$, and (D) model compound $\mathbf{4}$ in $\mathrm{CDCl}_{3}$ and (E) $\mathrm{P} \mathbf{1 b} / \mathbf{2} \mathbf{b} / \mathbf{3}$ in DMSO$-d_{6}$. 
(A)

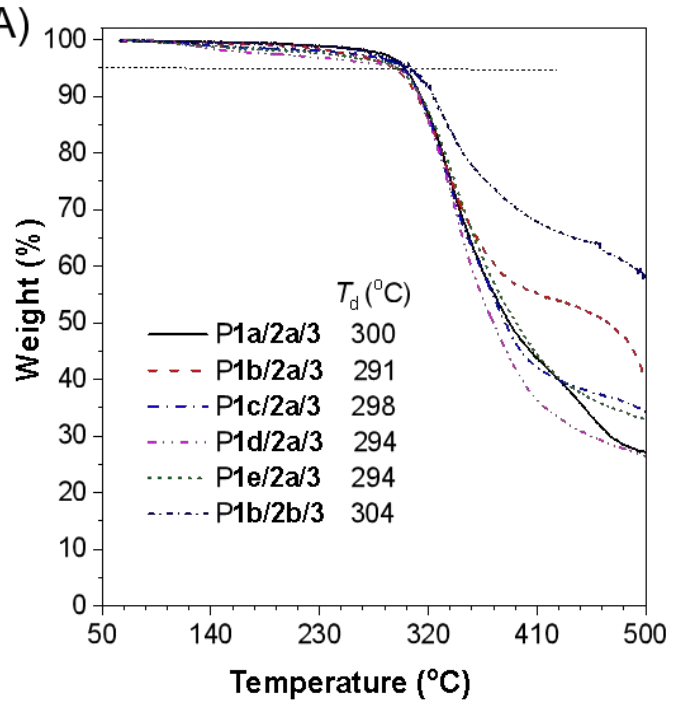

(B)

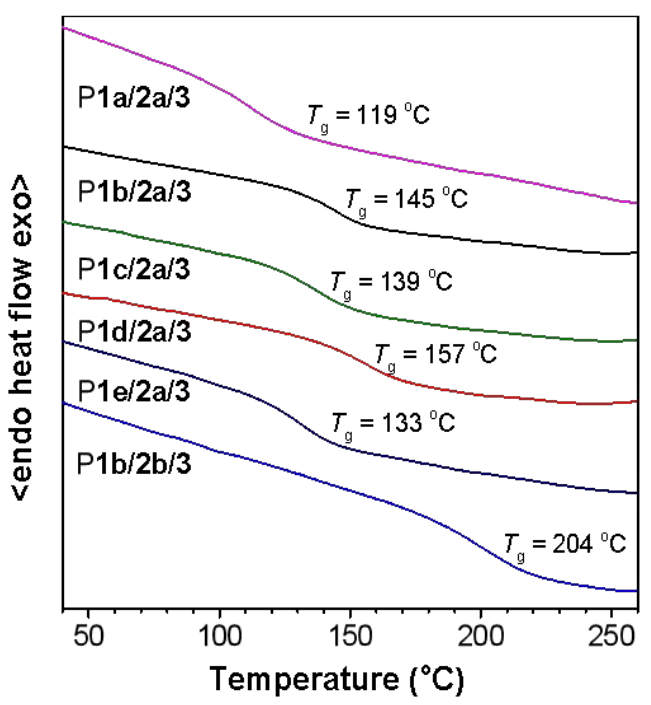

Figure S19. (A) TGA thermograms of $\mathrm{P} 1 \mathbf{a}-\mathbf{e} / \mathbf{2} \mathbf{a}-\mathbf{b} / \mathbf{3}$ recorded under nitrogen at a heating rate of 10 ${ }^{\circ} \mathrm{C} / \mathrm{min}$. (B) DSC thermograms of P1a-e/2a-b/3 recorded under nitrogen during the second heating cycle at a heating rate of $10{ }^{\circ} \mathrm{C} / \mathrm{min}$.

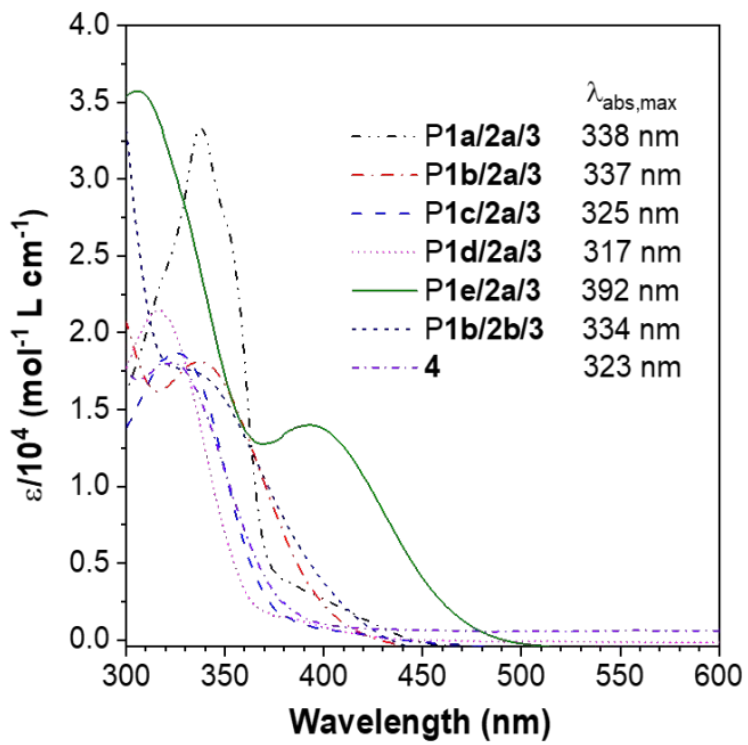

Figure S20. UV spectra and the maximum absorption wavelength of P1a-e/2a-b/3 and 4 in DMF solutions. Solution concentration: $10 \mu \mathrm{M}$. 

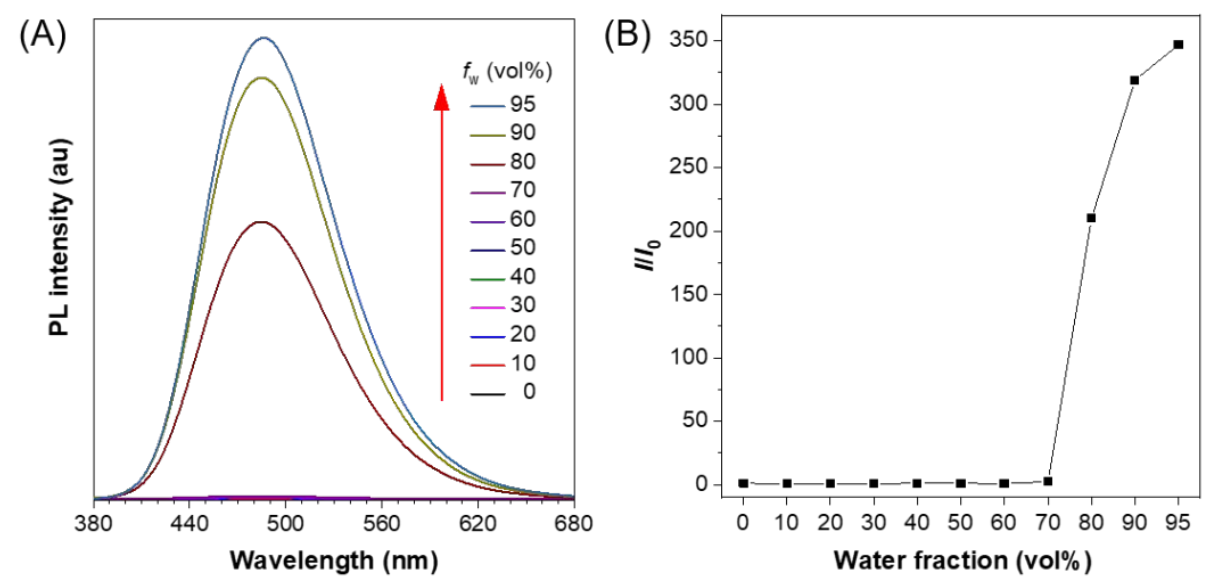

Figure S21. PL spectra model compound 4 in DMF/water mixtures with different water fractions $\left(f_{\mathrm{w}}\right)$. Solution concentration: $10 \mu \mathrm{M}$. Excitation wavelength $=325 \mathrm{~nm}$.

(A)

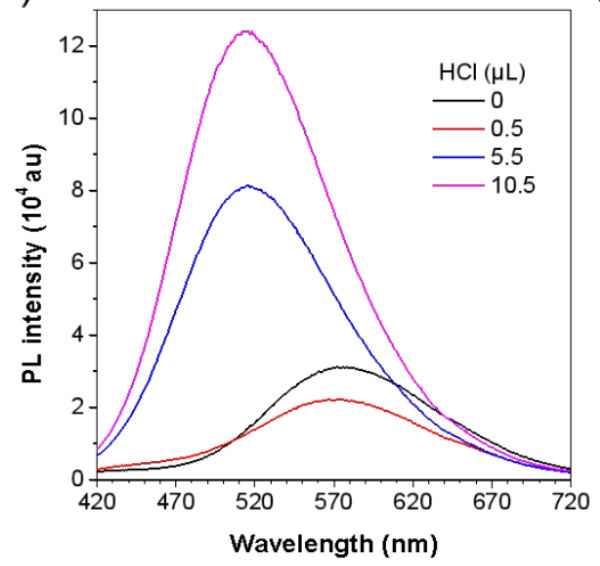

(B)

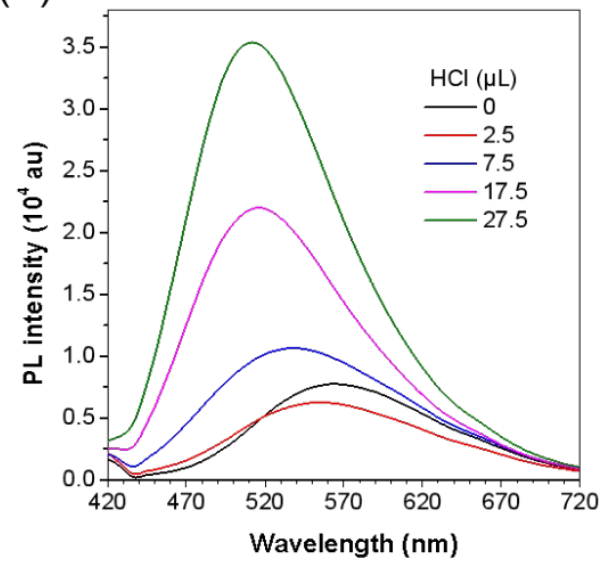

Figure S22. Emission spectra of P1e/2a/3 in (A) DMF and (B) $90 \%$ water $+10 \%$ DMF with the addition of different volume of $\mathrm{HCl}$ aqueous solution $(1.0 \mathrm{M})$. Polymer concentration: $10 \mu \mathrm{M}$. Excitation wavelength $=365 \mathrm{~nm}$.

(A)

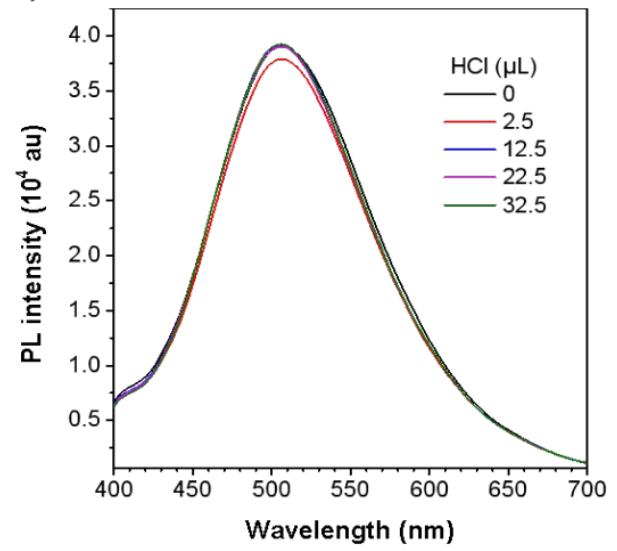

(B)

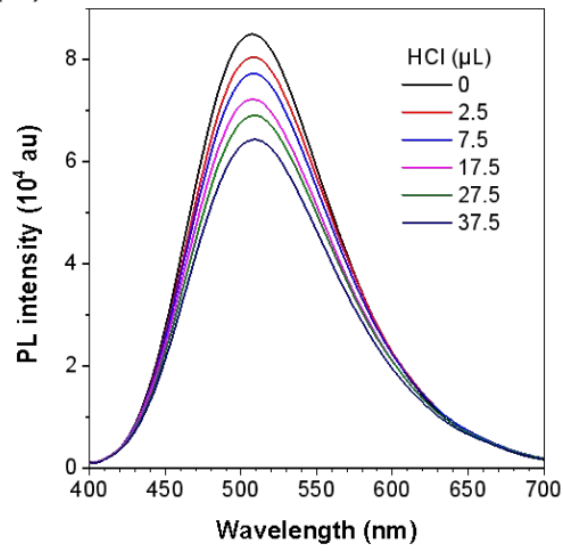

Figure S23. Emission spectra of P1b/2a/3 in (A) DMF and (B) $90 \%$ water $+10 \%$ DMF with the addition of different volume of $\mathrm{HCl}$ aqueous solution $(1.0 \mathrm{M})$. Polymer concentration: $10 \mu \mathrm{M}$. Excitation wavelength $=340 \mathrm{~nm}$. 

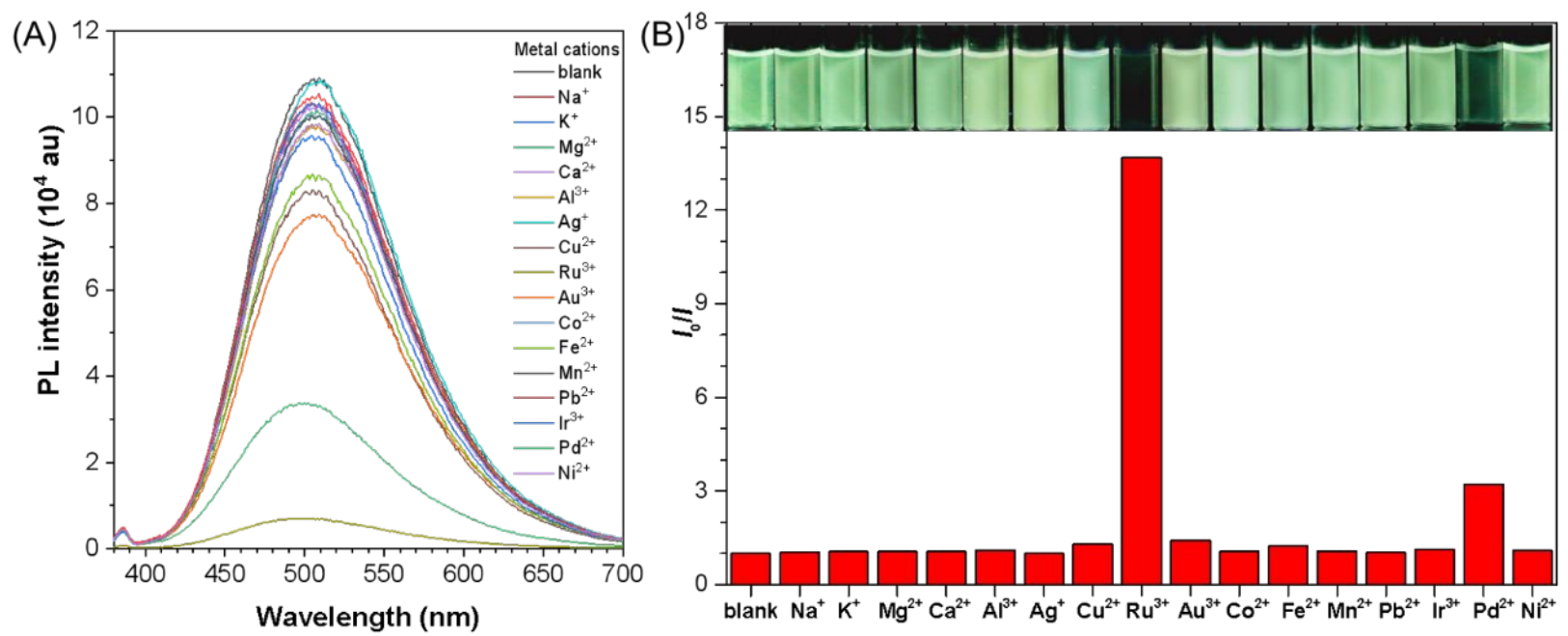

Figure S24. Fluorescence detection of $\mathrm{Ru}^{3+}$ using P1b/2a/3. (A) Emission spectra of $\mathrm{P} \mathbf{1 b} / \mathbf{2 a} / \mathbf{3}(10 \mu \mathrm{M})$ in $\mathrm{DMF} /$ water mixtures with a water fraction of $90 \%$ containing different metal cations $(100 \mu \mathrm{M})$. Excitation wavelength $=365 \mathrm{~nm}$. (B) Relative intensity $\left(I_{0} / I\right)$ of $\mathbf{P} \mathbf{1 b} / \mathbf{2 a} / \mathbf{3}$ in DMF/water mixtures with a water fraction of $90 \%$ containing different metal ions. $I_{0}=$ fluorescence intensity in the absence of metal cations. Inset: fluorescence photographs of $\mathbf{P} \mathbf{1 b} / \mathbf{2 a} / \mathbf{3}$ in DMF/water mixtures with a water fraction of $90 \%$ containing different metal ions. The photos were taken under $365 \mathrm{~nm}$ UV irradiation.

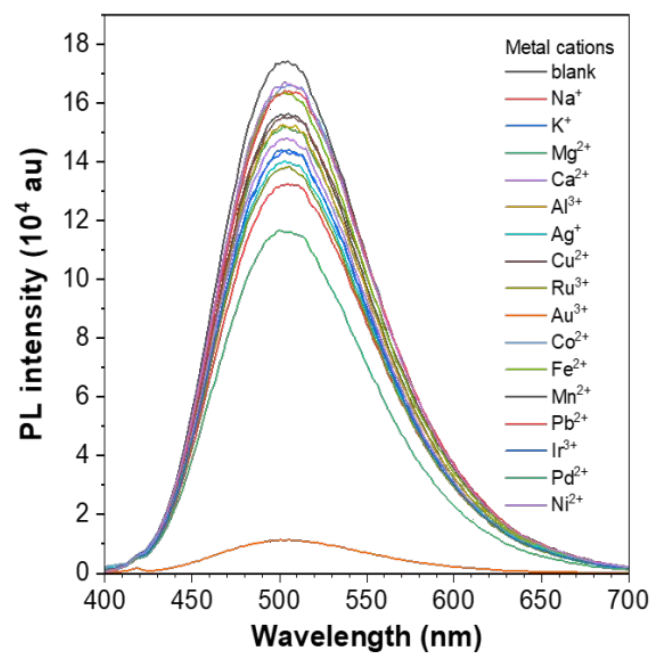

Figure S25. Emission spectra of P1e/2a/3 $(10 \mu \mathrm{M})$ in DMF/water mixtures with $90 \%$ aqueous buffer solution $(\mathrm{pH}=1)$ containing different metal cations $(10 \mu \mathrm{M})$. Excitation wavelength $=365 \mathrm{~nm}$. 


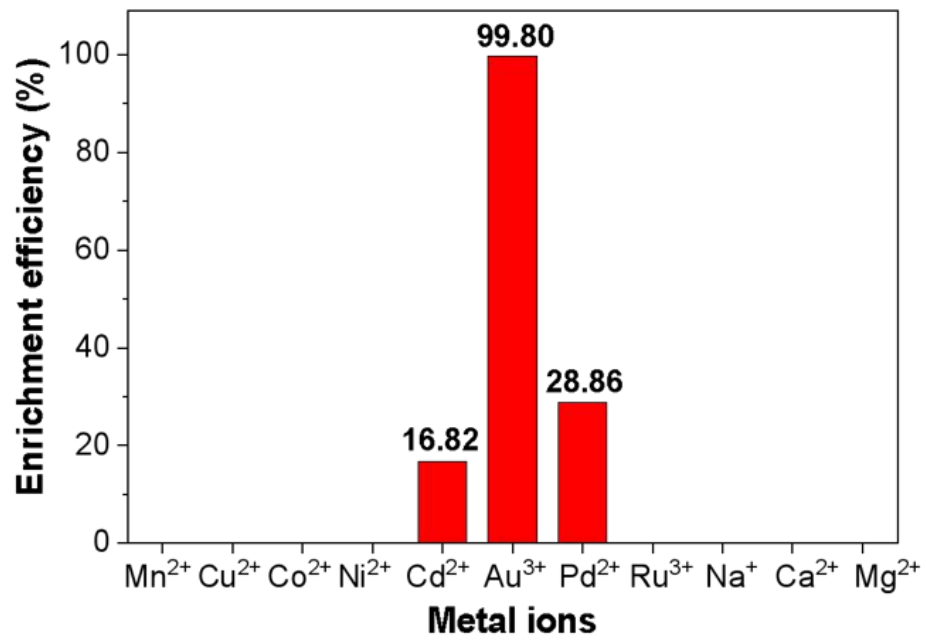

Figure S26. The enrichment efficiency of different metal ions using the solid powder of P1e/2a/3. $\left[\mathrm{M}^{\mathrm{n}+}\right]_{0}$ $=100 \mathrm{mg} / \mathrm{L}, \mathrm{V}_{\mathrm{M}}{ }^{\mathrm{n}+}=2 \mathrm{~mL}, \mathrm{~m}_{\mathrm{P} 1 \mathrm{e} / 2 \mathrm{a} / 3}=4 \mathrm{mg}$. Polymer powder and the aqueous solution of metal ions were stirred at room temperature for $1 \mathrm{~h}$ before centrifugation.
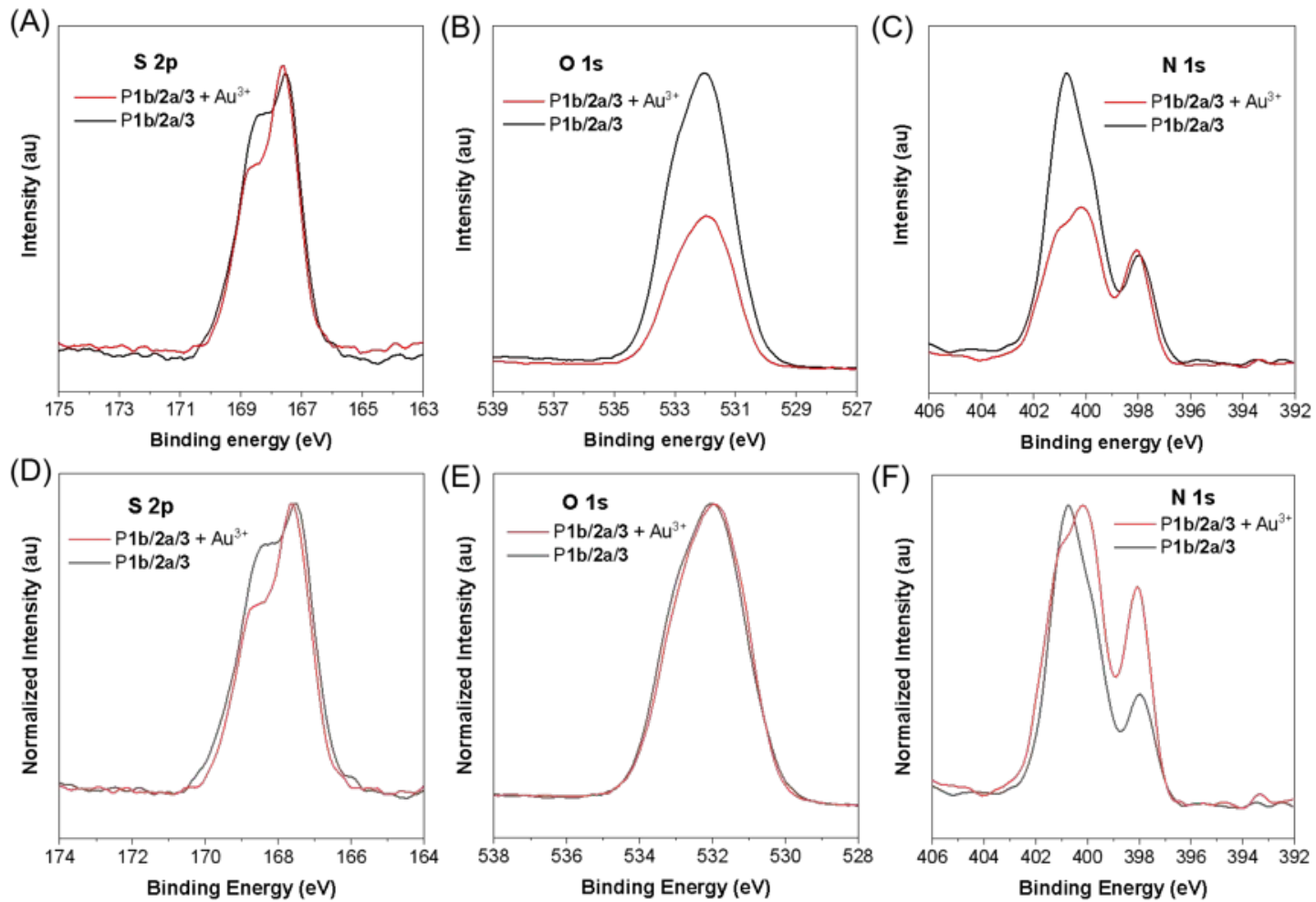

Figure S27. (A-C) XPS spectra and (D-F) the associated normalized XPS spectra for (A and D) S 2p, (B and E) $\mathrm{O} 1 \mathrm{~s}$, and $(\mathrm{C}$ and $\mathrm{F}) \mathrm{N} 1 \mathrm{~s}$ of $\mathrm{P} \mathbf{1 b} / \mathbf{2} \mathbf{a} / \mathbf{3}$ and $\mathrm{P} \mathbf{1 b} / \mathbf{2} \mathbf{a} / \mathbf{3}-\mathrm{Au}^{3+}$. 

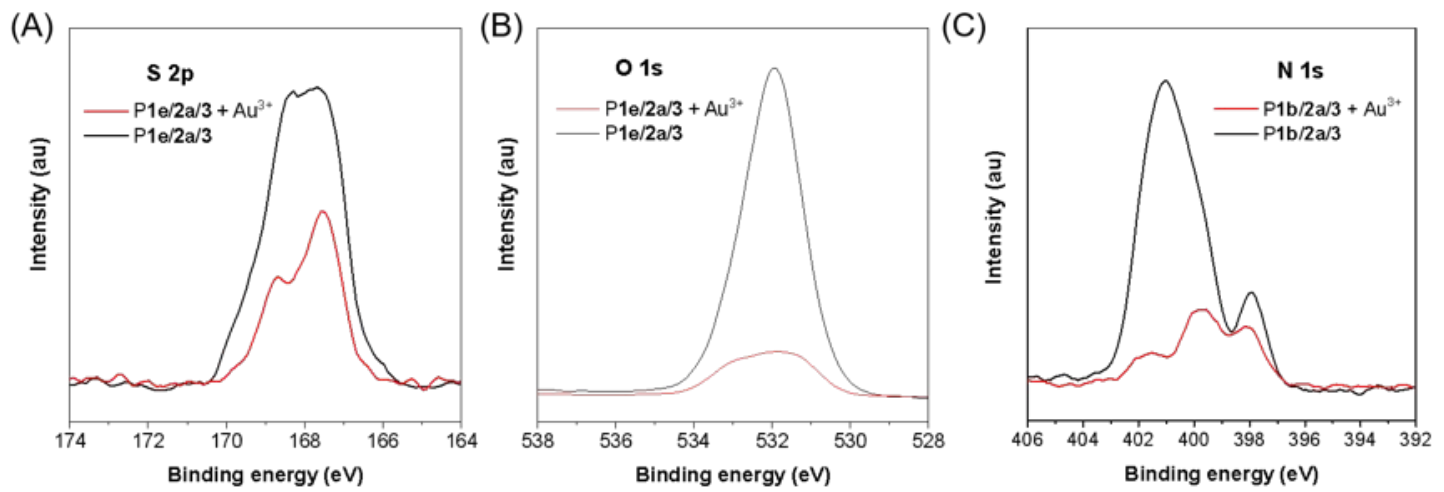

Figure S28. XPS spectra for (A) S 2p, (B) O 1s, and (C) N 1s of P1e/2a/3 and P1e/2a/3-Au ${ }^{3+}$.
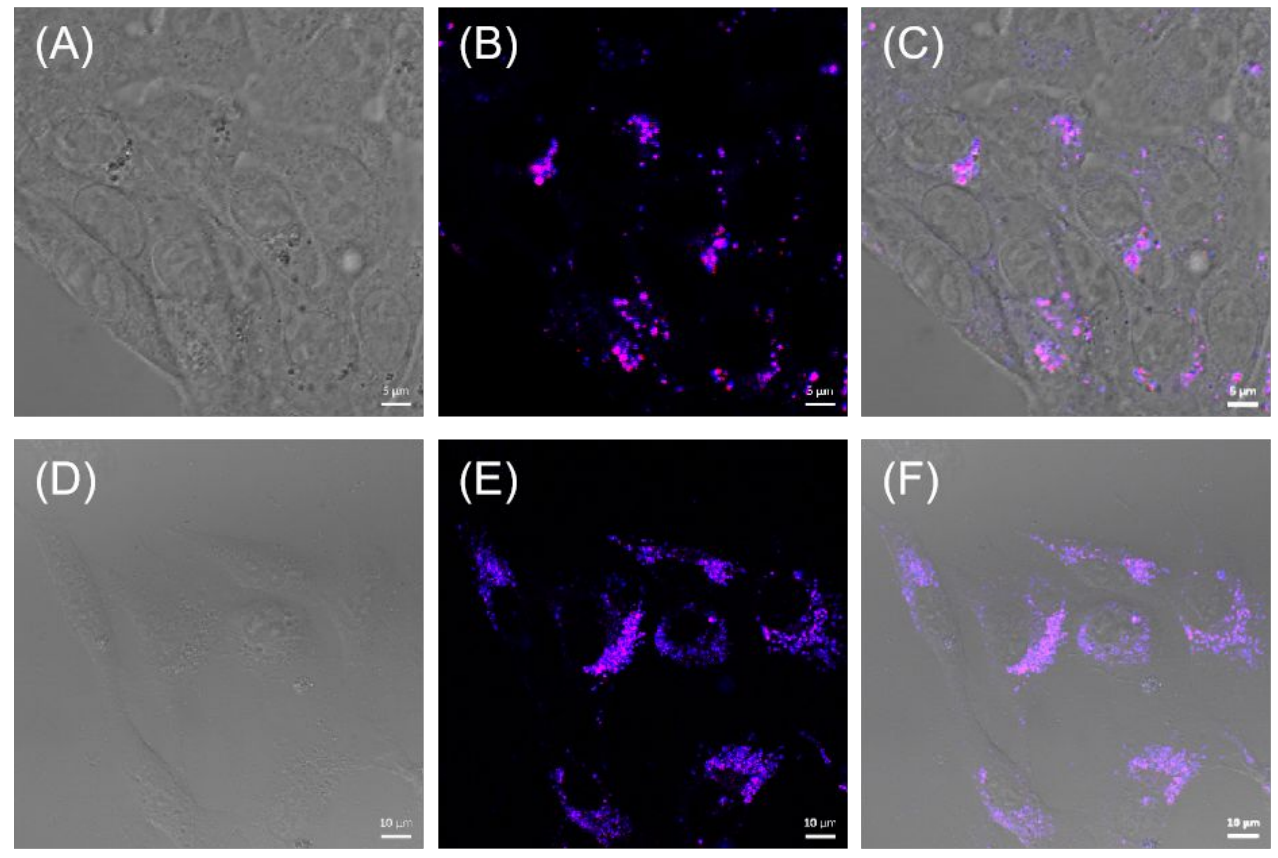

Figure S29. (A) Bright-field images, (B) Fluorescence images, and (C) the associated merged images of 4T1 cells stained with $10 \mu \mathrm{M}$ of $\mathrm{P} \mathbf{1 b} / \mathbf{2 a} / \mathbf{3}$. Scale bar $=5 \mu \mathrm{m}$. (D) Bright-field images, (E) Fluorescence images, and $(\mathrm{F})$ the associated merged images of $3 \mathrm{~T} 3$ cells stained with $10 \mu \mathrm{M}$ of $\mathrm{P} \mathbf{1 b} / \mathbf{2 a} / \mathbf{3}$. Scale bar $=$ $10 \mu \mathrm{m}$. Excitation wavelength: $405 \mathrm{~nm}$; emission filter: 450-650 nm.

\section{Reference}

[1] a) H. Q. Wu, H. K. Li, R. T. K. Kwok, E. G. Zhao, J. Z. Sun, A. J. Qin, B. Z. Tang, Sci. Rep. 2014, 4, 5107; b) A. R. Katritzky, J. W. Rogers, R. M. Witek, A. V. Vakulenko, P. P. Mohapatra, P. J. Steel, R. Damavarapu, J. Energ. Mater. 2007, 25, 79. c) B. Yao, J. Mei, J. Li, J. Wang, H. Wu, J. Z. Sun, A. Qin, B. Z. Tang, Macromolecules 2014, 47, 1325. d) J. Wang, B. Li, D. Xin, R. Hu, Z. Zhao, A. Qin, B. Z. Tang, Polym. Chem. 2017, 8, 2713.

[2] W. Huang, M. Bender, K. Seehafer, I. Wacker, R. R. Schröder, U. H. F. Bunz, Macromol. Rapid Commun. 2019, 40, 1800774.

[3] B. Yao, C. Shen, Z. Liang, Y. Zhang, J. Org. Chem. 2014, 79, 936. 